\title{
Evaluation of Volatile Organic Compounds in Two Mojave Desert Basins-Mojave River and Antelope Valley-in San Bernardino, Los Angeles, and Kern Counties, California, June-October 2002
}

Scientific Investigations

Report 2004-5248-Version 1.01

\section{Prepared in cooperation with the}

CALIFORNIA STATE WATER RESOURCES CONTROL BOARD

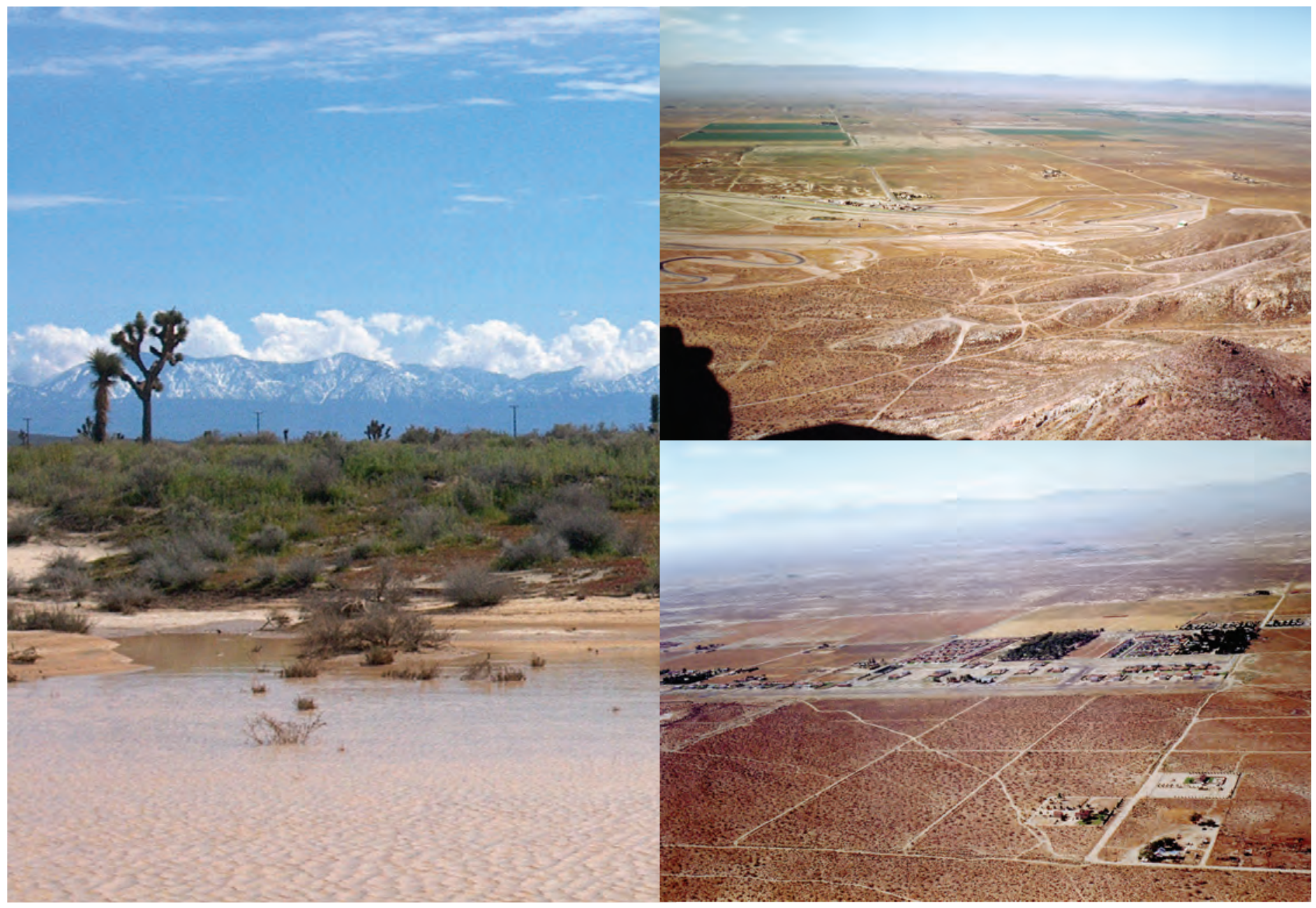


Photographs on front cover:

Left: Edwards Air Force Base, Mojave Desert with San Gabriel Mountains in background, California. Photograph by Michelle Sneed, U.S. Geological Survey.

Right: Antelope Valley within the western Mojave Desert, California. Photographs by Diane Rewis, U.S. Geological Survey. 


\section{Evaluation of Volatile Organic Compounds in Two Mojave Desert Basins-Mojave River and Antelope Valley-in San Bernardino, Los Angeles, and Kern Counties, California, June-October 2002}

By Jill N. Densmore, Kenneth Belitz, Michael T. Wright, Barbara J. Dawson, Tyler Johnson, and G. Bryant Hudson

Scientific Investigations Report 2004-5248 


\section{U.S. Department of the Interior \\ Gale A. Norton, Secretary \\ U.S. Geological Survey \\ Charles G. Groat, Director}

U.S. Geological Survey, Reston, Virginia: 2005

For sale by U.S. Geological Survey, Information Services
Box 25286, Denver Federal Center
Denver, CO 80225
For more information about the USGS and its products:
Telephone: 1-888-ASK-USGS
World Wide Web: http://www.usgs.gov/

Any use of trade, product, or firm names in this publication is for descriptive purposes only and does not imply endorsement by the U.S. Government.

Although this report is in the public domain, permission must be secured from the individual copyright owners to reproduce any copyrighted materials contained within this report.

Suggested citation:

Densmore, J.N., Belitz, Kenneth, Wright, M.T., Dawson, B.J., Johnson, Tyler, and Hudson, G. Bryant, 2005, Evaluation of Volatile Organic Compounds in Two Mojave Desert Basins-Mojave River and Antelope Valley-in San Bernardino, Los Angeles, and Kern Counties, California, June-October 2002: U.S. Geological Survey Scientific Investigations Report 2004-5248, 40 p. 


\section{Contents}

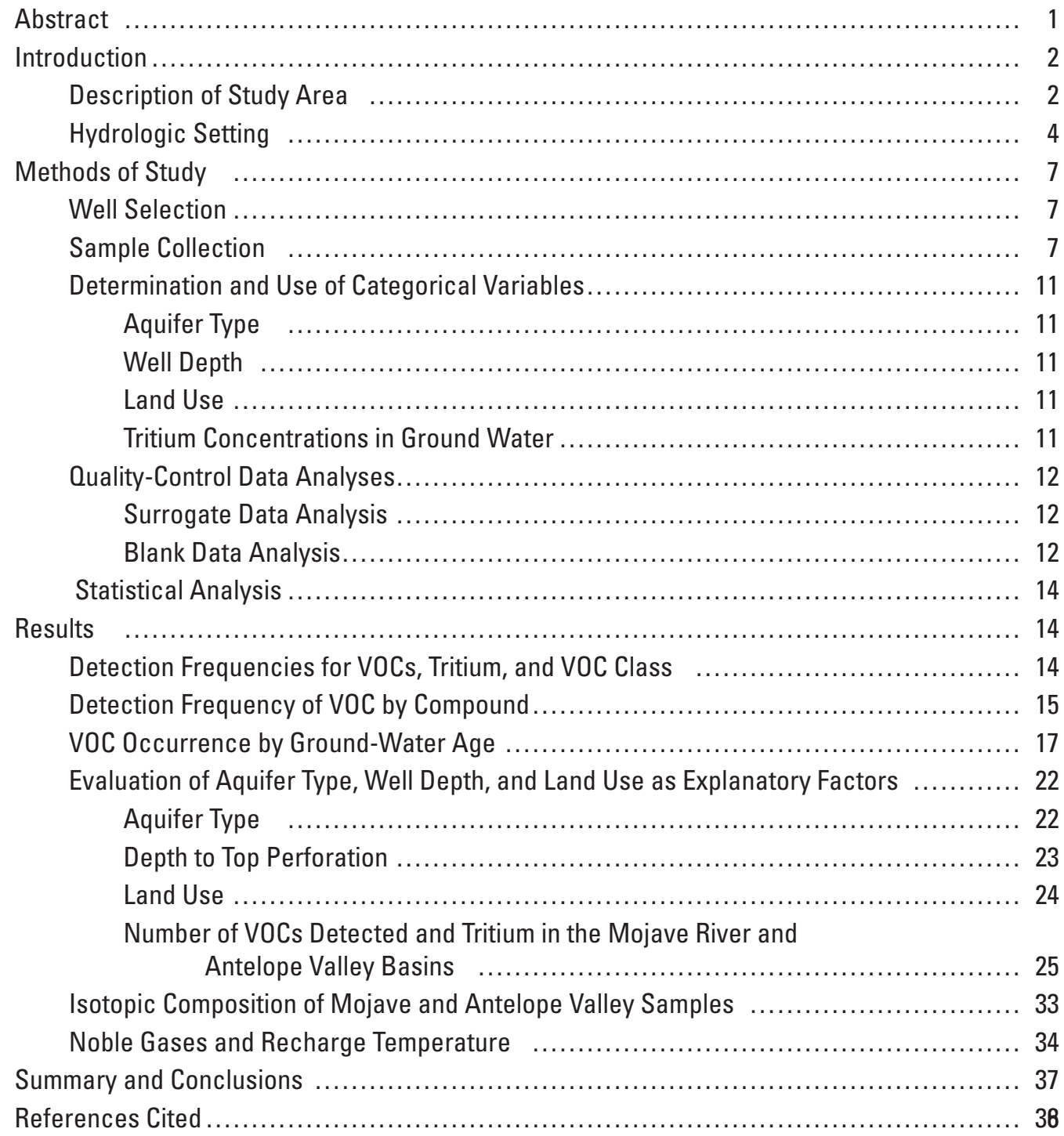




\section{Figures}

Figure 1. Map showing location of the Mojave River Basin (California Aquifer Susceptibility [MJCAS]) and the Antelope Valley Basin (California Aquifer Susceptibility [AVCAS]), San Bernardino, Los Angeles, and Kern Counties, California

Figure 2. Map showing location of all existing and sampled wells in the $(A)$ Mojave River Basin and (B) Antelope Valley Basins, California....

Figure 3. Graphs showing detection frequency of $(A)$ volatile organic compounds (VOC) and tritium and $(B)$ specific classes of VOCs for the samples from the Mojave River and

Antelope Valley Basins, California

Figure 4. Graph showing detection frequencies of volatile organic compounds (VOC), in order of detection frequency, for samples from the Mojave River and Antelope Valley Basins, California

Figure 5. Graphs showing $(A)$ detection frequency of volatile organic compounds (VOC) in the Mojave River and Antelope Valley samples by relative age, and the number of VOCs detected by ground-water age for samples from $(B)$ the Mojave River Basin and $(C)$ the Antelope Valley Basin, California

Figure 6. Graphs showing volatile organic compounds (VOC) and tritium detection frequencies by aquifer type for $(A)$ the Mojave River Basin and $(B)$ the Antelope Valley Basin, California

Figure 7. Graphs showing volatile organic compounds (VOC) and tritium detection frequencies by depth for $(A)$ the Mojave River Basin and $(B)$ the Antelope Valley Basin, California

Figure 8. Graphs showing volatile organic compounds (VOC) and tritium detection frequencies by degree of urbanization for $(A)$ the Mojave River Basin and $(B)$ the Antelope Valley Basin, California

Figure 9. Maps showing location of sampling sites, volatile organic compound (VOC) detections, and relative age of water in the $(A)$ Mojave River and $(B)$ Antelope Valley Basins, San Bernardino, Los Angeles, and Kern Counties, California

Figure 10. Maps showing location of sampling sites, volatile organic compound (VOC) detections, and age of water in the (A \& B) Mojave River and (C \& D) Antelope Valley Basins, San Bernardino, Los Angeles, and Kern Counties, California

Figure 11. Graphs showing variation of $(A)$ depths of top of perforations of wells and $(B)$ land use in the Mojave River and Antelope Valley Basins, California

Figure 12. Graph showing isotopic composition of ground-water samples from the Mojave River and Antelope Valley Basins, San Bernardino, Los Angeles, and Kern Counties, California

Figure 13. Maps showing location of sampling sites and estimated recharge temperature of water in the (A) Mojave River and (B) Antelope Valley Basins, San Bernardino, Los Angeles, and Kern Counties, California 


\section{Tables}

Table 1. Selected construction data for wells sampled in the Mojave River and the Antelope Valley Basins (California Aquifer Susceptibility [CAS]) in San Bernardino, Los Angeles, and Kern Counties, California, June-0ctober 2002

Table 2. Volatile organic compounds and primary use or source analyzed for in this study... 10

Table 3. Summary of quality-control data for volatile organic compounds (VOC) detected in field blanks and associated source-solution blanks collected during the Mojave River and the Antelope Valley Basin studies, San Bernardino, Los Angeles, and Kern Counties, California, 2002.

Table 4A. Summary of volatile organic compound (VOC) concentrations listed in order of detection frequency for wells sampled during 2002 in the floodplain aquifer in the Mojave River Basin California Aquifer Susceptibility (MJCAS) study, San Bernardino County, California

Table 4B. Summary of volatile organic compound (VOC) concentrations listed in order of detection frequency for wells sampled during 2002 in the regional aquifer in the Mojave River Basin (California Aquifer Susceptibility [MJCAS]) study, San Bernardino County, California

Table 4C. Summary of volatile organic compound (VOC) concentrations listed in order of detection frequency for wells sampled during 2002 in the sewered subset of the regional aquifer in the Mojave River Basin (California Aquifer Susceptibility [MJCAS]) study, San Bernardino County, California

Table 4D. Summary of volatile organic compound (VOC) concentrations listed in order of detection frequency for wells sampled during 2002 in the Antelope Valley Basin (California Aquifer Susceptibility [AVCAS]) study, San Bernardino County,

California

Table 5. Summary of tritium, noble gases, and estimated apparent age for samples collected in 2002 in the Mojave River Basin and Antelope Valley Basin (California Aquifer Susceptibility [CAS]) study, San Bernardino, Los Angeles, and Kern Counties, California 


\section{Conversion Factors, Water-Quality Information, Abbreviations and Acronyms}

Conversion Factors

\begin{tabular}{lcl}
\hline Multiply & By & To obtain \\
\hline square mile $\left(\mathrm{mi}^{2}\right)$ & 2.590 & square kilometer $\left(\mathrm{km}^{2}\right)$ \\
foot (ft) & 0.3048 & meter $(\mathrm{m})$ \\
inch (in.) & 2.54 & centimeter $(\mathrm{cm})$ \\
milliliter $(\mathrm{mL})$ & 0.0338 & ounce $(\mathrm{oz})$ \\
\hline
\end{tabular}

Temperature in degrees Celsius $\left({ }^{\circ} \mathrm{C}\right)$ may be converted to degrees Fahrenheit $\left({ }^{\circ} \mathrm{F}\right)$ as follows:

$$
{ }^{\circ} \mathrm{F}=\left(1.8 \times{ }^{\circ} \mathrm{C}\right)+32
$$

\section{WATER-QUALITY INFORMATION}

Concentrations of chemical constituents in water are given in milligrams per liter (mg/L) or micrograms per liter $(\mu \mathrm{g} / \mathrm{L})$. Milligrams per liter is approximately equivalent to parts per million. Micrograms per liter is approximately equivalent to parts per billion.

Data for the isotopes oxygen-18 and deuterium are reported in delta $(\delta)$ notation as per mil (parts per thousand); tritium data are reported in picocuries per liter ( $\mathrm{pCi} / \mathrm{L})$.

$\begin{array}{ll}\text { ABBREVIATIONS AND ACRONYMS } \\ \text { AVCAS } & \text { Antelope Valley California Aquifer Susceptibility } \\ \text { BTEX } & \text { benzene, toluene, ethylbenzene, xylene } \\ \text { CAS } & \text { California Aquifer Susceptibility } \\ \text { E-coded } & \text { coded as estimated } \\ \text { GAMA } & \text { Ground-Water Ambient Monitoring Program } \\ \text { GWSI } & \text { Ground-Water Site Inventory } \\ \text { LLNL } & \text { Lawrence Livermore National Laboratory } \\ \text { LRL } & \text { laboratory reporting level } \\ \text { MJCAS } & \text { Mojave River California Aquifer Susceptibility } \\ \text { MJFCAS } & \text { Mojave River California Aquifer Susceptibility for the floodplain aquifer } \\ \text { MJRCAS } & \text { Mojave River California Aquifer Susceptibility for the regional aquifer } \\ \text { MJSCAS } & \text { Mojave River California Aquifer Susceptibility for the sewered subset } \\ \text { MTBE } & \text { methyl tert-butyl ether } \\ \text { NAWOA } & \text { National Water-Quality Assessment } \\ \text { NWOL } & \text { National Water Quality Laboratory } \\ \text { P } & \text { probability } \\ \text { PCE } & \text { tetrachloroethylene } \\ \text { OC } & \text { Quality Control } \\ & \end{array}$


SWRCB State Water Resources Control Board

TCE trichloroethylene

THM trihalomethane

VOC Volatile Organic Compound

USEPA U.S. Environmental Protection Agency

USGS U.S. Geological Survey

$\mathrm{cm}^{3} \mathrm{STP} / \mathrm{g} / \mathrm{yr}$ cubic centimeter at standard temperature and pressure per gram per year

$\delta^{18} 0 \quad$ oxygen-18 in delta notation

$\delta D \quad$ deuterium in delta notation

\%o per mil

\section{Well-Numbering System}

Wells are identified and numbered according to their location in the rectangular system for the subdivision of public lands. Identification consists of the township number, north or south; the range number, east or west; and the section number. Each section is divided into sixteen 40acre tracts lettered consecutively (except I and O), beginning with " $\mathrm{A}$ " in the northeast corner of the section and progressing in a sinusoidal manner to " $\mathrm{R}$ " in the southeast corner. Within the 40-acre tract, wells are sequentially numbered in the order they are inventoried. The final letter refers to the base line and meridian. In California, there are three base lines and meridians; Humboldt (H), Mount Diablo (M), and San Bernardino (S). All wells in the study area are referenced to the San Bernardino base line and meridian (S). Well numbers consist of 15 characters and follow the format 006N004W30K003S.

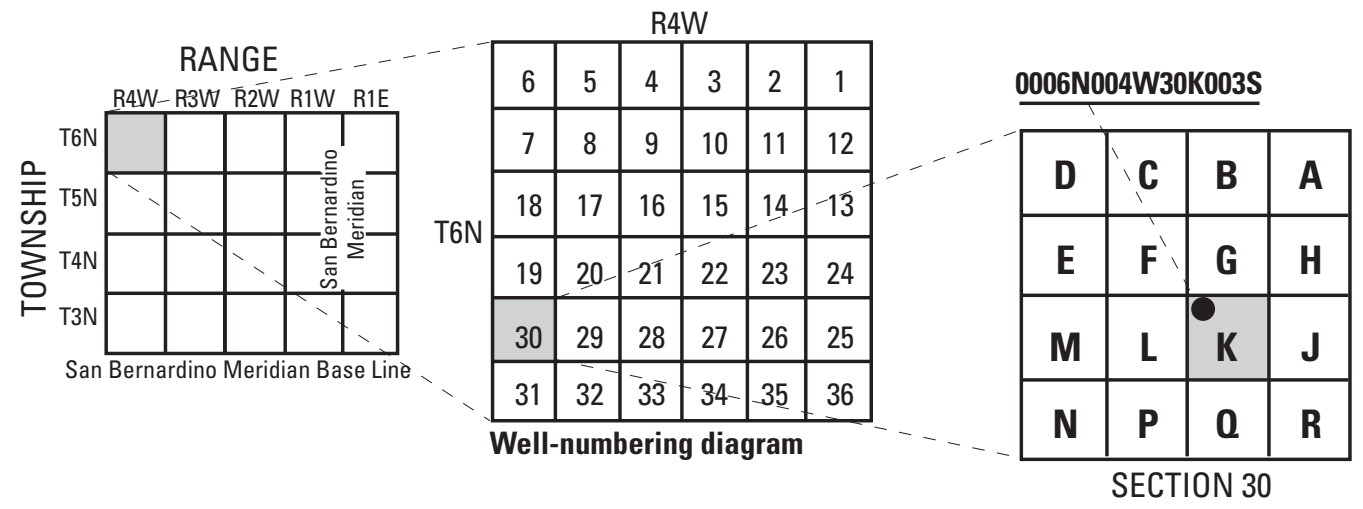





\title{
Evaluation of Volatile Organic Compounds in Two Mojave Desert Basins-Mojave River and Antelope Valley- in San Bernardino, Los Angeles, and Kern Counties, California, June-October 2002
}

\author{
By Jill N. Densmore, Kenneth Belitz, Michael T. Wright, Barbara J. Dawson, Tyler Johnson, and \\ G. Bryant Hudson
}

\section{Abstract}

The California Aquifer Susceptibility Assessment of the Ground-Water Ambient Monitoring and Assessment Program was developed to assess water quality and susceptibility of ground-water resources to contamination from surficial sources. This study focuses on the Mojave River and the Antelope Valley Ground-Water Basins in southern California.

Volatile organic compound (VOC) data were evaluated in conjunction with tritium and helium data to determine a potential correlation with aquifer type, depth to top of perforations, and land use to VOC distribution and occurrence in the Mojave River and the Antelope Valley Basins. Detection frequencies for VOCs were compiled and compared to assess the distribution in each area. Explanatory variables were evaluated by comparing detection frequencies for VOCs and tritium and the number of compounds detected. Thirty-three wells were sampled in the Mojave River Basin (9 in the floodplain aquifer, 15 in the regional aquifer, and 9 in the sewered subset of the regional aquifer). Thirty-two wells were sampled in the Antelope Valley Basin. Quality-control samples also were collected to identify, quantify, and document bias and variability in the data.

Results show that VOCs generally were detected slightly more often in the Antelope Valley Basin samples than in the Mojave River Basin samples. VOCs were detected more frequently in the floodplain aquifer than in the regional aquifer and the sewered subset. Tritium was detected more frequently in the Mojave River Basin samples than in the Antelope Valley Basin samples, and it was detected more frequently in the floodplain aquifer than in the regional aquifer and the sewered subset. Most of the samples collected in both basins for this study contained old water (water recharged prior to 1952). In general, in these desert basins, tritium need not be present for VOCs to be present. When VOCs were detected, young water (water recharged after 1952) was slightly more likely to be contaminated than old water.
Trihalomethanes (THM) were detected less frequently in the Mojave River Basin samples than in the Antelope Valley Basin samples. The THMs that were detected in the Mojave River Basin were detected more frequently in the floodplain aquifer than in the regional aquifer and sewered subset. Solvents (such as trichloroethane [TCE] and tetrachloroethylene [PCE]) were detected more frequently in the Mojave River samples than in the Antelope Valley samples. In the Mojave River Basin samples, solvents were detected less frequently in the floodplain aquifer than in the regional aquifer and the sewered subset. Benzene, toluene, ethylbenzene and xylene (BTEX) were not detected in either study area. Methyl tertbutyl ether (MTBE) was detected in one sample from both the Mojave River and Antelope Valley Basins.

The most frequently detected compound (detected in more than 10 percent of the wells) in the Mojave River Basin was chloroform. The two most frequently detected compounds in the Antelope Valley Basin were chloroform and PCE.

In the Mojave River Basin, aquifer type and land use within 1,640 ft (foot)(500 meters) of the well head were not statistically correlated with the number of VOCs detected, although VOCs were detected more frequently in the floodplain aquifer than in the regional aquifer and the sewered subset. Depth to the top of the perforations was an explanatory factor for the number of VOCs detected in the Mojave River Basin; the detection frequency was greater for shallow wells than for deep wells.

In the Antelope Valley Basin, neither aquifer type, depth to the top of the perforations, nor land use within 1,640 ft of the well head were explanatory factors for the number of VOCs detected. Although aquifer type and depth to top of the perforations did explain the presence of tritium in the Mojave River Basin, land use within 1,640 ft of the well head was not a statistically significant explanatory factor for the presence of tritium in this basin. Aquifer type, depth to the top of the perforations, and land use within 1,640 ft of the well head were not statistically significant explanatory factors for the presence of tritium in the Antelope Valley Basin. 
The spatial distribution of VOCs in the Mojave River Basin does not have any apparent pattern that can be associated to one direct source. Although VOCs were detected more often in samples from wells in the floodplain aquifer than in the samples from the regional aquifer and the sewered subset, the VOC detections in wells in the regional aquifer generally contained more than one compound, unlike the VOCs detections in wells in the floodplain aquifer and the sewered subset, which contained only one compound.

The areal distribution of VOCs in the Antelope Valley Basin samples appears to be concentrated in the urban areas and near the mountain front. Differences in VOC detection frequency and distribution between the Mojave River and the Antelope Valley Basins probably were related to differences in urban land use between the two basins.

Tritium/helium-3 and helium-4 ground-water ages in the Mojave River Basin ranged from as young as 6 years in the floodplain aquifer to about 40,000 years in the regional aquifer. Tritium/helium-3 and helium-4 ground-water ages in the Antelope Valley Basin ranged from less than 25 years near the mountain front to about 35,000 years farther north of the mountains.

The oxygen-18 $\left({ }^{18} \mathrm{O}\right)$ and deuterium (D) (expressed in delta notation $[\delta]$ ) isotopic composition of the ground-water samples from the Mojave River and the Antelope Valley Basins indicates that recharge along the Mojave River and in the sewered subset resulted from precipitation from a slightly different storm track and recharge elevation than recharge in the regional aquifer and in the Antelope Valley Basin. The isotopic composition was not related to the occurrence of VOCs.

Noble gases were used to calculate ground-water recharge temperatures. Recharge temperatures in ground water in the Mojave River Basin ranged from $7.8^{\circ}$ to $20^{\circ} \mathrm{C}$. Temperatures were generally lowest in the floodplain aquifer and were $2^{\circ}$ to $4^{\circ} \mathrm{C}$ warmer in the sewered subset and $4^{\circ}$ to $5^{\circ} \mathrm{C}$ warmer in the the regional aquifer. Recharge temperatures of ground water in the Antelope Valley Basin ranged from $11.6^{\circ} \mathrm{C}$ to $20.7^{\circ} \mathrm{C}$ and generally were $4^{\circ}$ to $5^{\circ} \mathrm{C}$ warmer than temperatures of ground water in the floodplain aquifer.

\section{Introduction}

Due to increased concern about the recent closures of public-supply wells and about the detection of chemicals such as methyl tert-butyl ether (MTBE) from gasoline and various solvents from industrial sources, a comprehensive ambient ground-water monitoring plan, the Ground-Water Ambient Monitoring and Assessment (GAMA) Program, was developed by the California State Water Resources Control Board (SWRCB). The primary objective of the GAMA Program is to assess the water quality and the relative susceptibility of ground-water resources to common contaminants from surficial sources. The focus of the GAMA Program is to collect new data and to identify and centralize the many sources of ground-water data and information available in California. The GAMA Program has two sampling components: the California Aquifer Susceptibility (CAS) Assessment (State Water Resources Control Board, 2003a), which focuses on publicsupply drinking-water wells, and the Voluntary Domestic Well Assessment (State Water Resources Control Board, 2003b), which focuses on private drinking-water wells.

Data were collected to evaluate the use of ground-water age (tritium) and low-level volatile organic compound (VOC) concentrations as indicators of the susceptibility of ground water to contamination. Age-dating provides information on the presence of young ground water (indicating recent recharge), and the analysis of low-level VOCs provides an "early warning" for potential VOC contamination. Since the widespread use of regulated chemicals following World War II, ground water recharged over the past 50 years can be considered more susceptible to contamination from various land-use activities. Additionally, low-level VOC analysis for compounds, such as MTBE, will allow water managers to identify potential trends in ground-water quality in their region and respond before concentrations reach action levels.

The CAS study was designed to sample public-supply wells in California. Sampling began in 2000 and ended in 2004, replaced by the GAMA comprehensive ground water monitoring program. Sampling and analysis was conducted by the U.S. Geological Survey (USGS) and the Lawrence Livermore National Laboratory (LLNL). Quality-control samples were collected to ensure that bias was not introduced as a result of sampling procedures. The CAS study areas for this assessment are the Mojave River and Antelope Valley Ground-Water Basins in the Mojave Desert of California.

\section{Description of Study Area}

The Mojave River (MJCAS) and the Antelope Valley (AVCAS) Basins lie in the Mojave River and the Antelope Valley surface-water drainages located in the western Mojave Desert of southern California (fig. 1). The Mojave Desert is a wedge-shaped block bounded by the San Andreas fault zone and the San Gabriel Mountains to the southwest, the San Bernardino Mountains to the southeast, the Garlock fault zone and the Tehachapi Mountains to the northwest, and the Colorado River on the east (Hewett, 1954). The Mojave River surface-water drainage encompasses approximately 3,800 $\mathrm{mi}^{2}$ (Stamos and others, 2001) and is located entirely within San Bernardino County (fig. 1). The Antelope Valley surface-water drainage covers about 2,200 $\mathrm{mi}^{2}$ (Londquist and others, 1993) and is located mostly within Los Angeles and Kern Counties. 


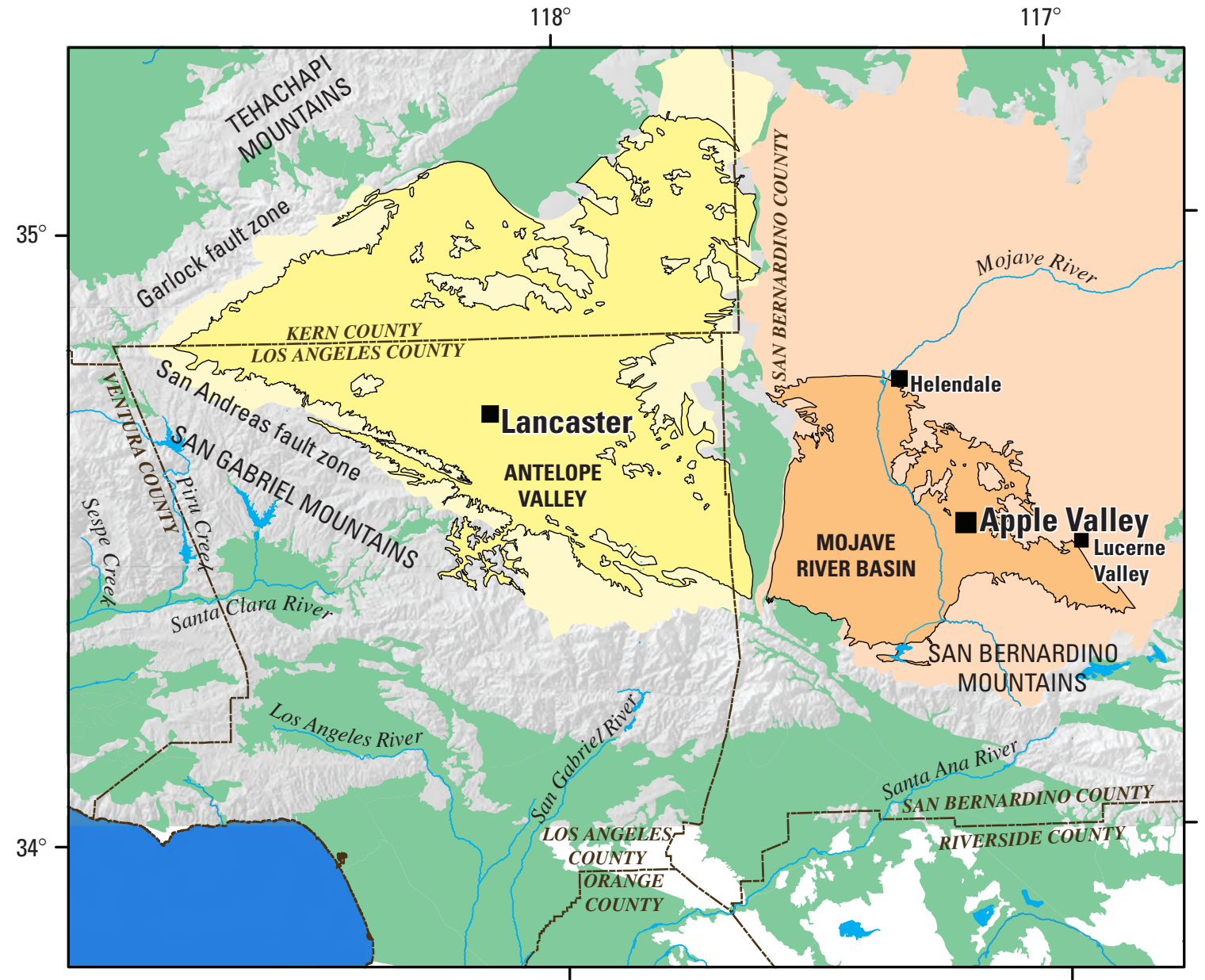

Base from U.S. Geological Survey digital elevation model 2002 Ground-water basin boundaries from California Albers Equal Area Projection: standard parallels $29^{\circ} 30^{\prime}$ and $45^{\circ} 30^{\prime}$ central meridian $-120^{\circ}$

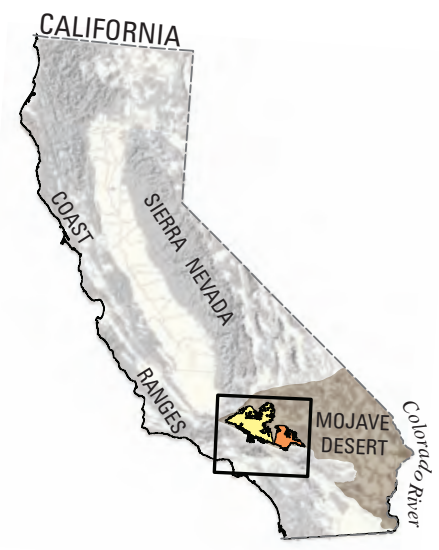

\section{EXPLANATION}

Mojave River Ground-Water Basin study area (MJCAS) Antelope Valley Ground-Water Basin study area (AVCAS) Mojave River Surface-Water Drainage Basin Antelope Valley Surface-Water Drainage Basin Department of Water Resources ground-water basins Consolidated rock

Figure 1. Location of the Mojave River Basin (California Aquifer Susceptibility [MJCAS]) and the Antelope Valley Basin (California Aquifer Susceptibility [AVCAS]), San Bernardino, Los Angeles, and Kern Counties, California. 
The main geographic and hydrologic feature of the Mojave River surface-water drainage is the Mojave River (fig. 2A), the headwaters of which are in the San Bernardino Mountains where annual precipitation is about $40 \mathrm{in}$. The mean annual precipitation in most of the basin is less than 6 in. (James, 1992). The Mojave River transects the surfacewater drainage a distance of about $120 \mathrm{mi}$ to its terminus at Silver Lake (dry) near Baker, California (not shown in fig. 2A). Except during storms and at select locations where ground water is forced to the surface by subsurface geologic structures, the Mojave River is dry downstream from the Forks of the Mojave River (reservoir), located near the base of the San Bernardino Mountains.

The main geographic and hydrologic features of Antelope Valley surface-water drainage are Rogers and Rosamond Lakes (dry lakes, also known as playas) (fig. 2B). Antelope Valley is a closed topographic basin with its lowest point at Rogers Lake (Londquist, 1995). Antelope Valley is in the rainshadow of the Tehachapi and the San Gabriel Mountains and has an average annual precipitation of about 4 in. (Londquist, 1995). Ground-water recharge originates primarily from the infiltration of surface-water runoff from the mountains along normally dry washes and creekbeds that extend into the alluvial basin.

The population in the desert has steadily increased. The main population centers in the Mojave River area are the towns of Adelanto, Apple Valley, Hesperia, and Victorville (fig. 2A), having a combined population of about 199,000 (derived from U.S. Census Bureau, 2000). The population in this area is expected to grow to about 500,000 by the year 2015 with much of the existing and projected future population concentrated in the Victorville area. The main population centers in the Antelope Valley area are Lancaster, Palmdale, Rosamond, and Edwards Air Force Base (fig. 2B), having a combined population of about 256,000 (U.S. Census Bureau, 2000). Historically, these desert areas have been known for their agricultural, industrial, and military land uses; the areas of these land uses have changed during the last several decades into a satellite community of Southern California's urban sprawl.

\section{Hydrologic Setting}

The Mojave River ground-water basin, as defined by the California Department of Water Resources (2003), covers about $645 \mathrm{mi}^{2}$ and lies within the larger Mojave River surfacewater drainage. It is bounded by the San Bernardino and the San Gabriel Mountains to the south and extends to the north to Helendale, to the east to the Lucerne Valley, and to the west to the Antelope Valley (fig. 1). The Mojave River ground-water basin boundary is formed by nonwater-bearing consolidated rocks that crop out in the surrounding mountains and hills, lie near the land surface forming ground-water divides, and underlie the alluvial deposits of the basin. The basin is filled with unconsolidated deposits consisting of gravel, sand, silt, and clay deposited by the recent Mojave River and the Pliocene-Pleistocene ancestral Mojave River, by tributary alluvial fans, and by older streams and alluvial fans that predate the origin of the Mojave River surface-water drainage basin (Stamos and others, 2001). The aquifer system consists of two aquifers - a floodplain aquifer that underlies the floodplain of the Mojave River and a regional aquifer that underlies and surrounds the floodplain aquifer. The floodplain aquifer consists of permeable recent river deposits of Holocene age and younger river deposits of Holocene to Pleistocene age (Stamos and others, 2001). The floodplain aquifer is recharged by surface-water infiltration along the Mojave River, the principal source of which is runoff from snowmelt and precipitation in the San Bernardino Mountains. The regional aquifer consists of unconsolidated older alluvium of the ancestral Mojave River of Pleistocene to Pliocene age and undifferentiated alluvium of Holocene to Pliocene age. The regional aquifer receives limited recharge that infiltrates the thick unsaturated zone (as much as 1,000 ft thick) near the mountain front. This study evaluated only the part of the Mojave River GroundWater Basin in the main urban area of Victor Valley, including the towns of Victorville, Apple Valley, Hesperia, Adelanto, and Helendale (fig. 2A), an area of about $160 \mathrm{mi}^{2}$. This area hereinafter is referred to as the Mojave River Basin.

Antelope Valley covers about 2,200 $\mathrm{mi}^{2}$ (Londquist and others, 1993). It is bounded on the southwest by the San Gabriel Mountains and the San Andreas fault zone and on the northwest by the Tehachapi Mountains and the Garlock fault zone (fig. 1). Three structural basins make up the Antelope Valley, which is filled with Tertiary and Quaternary sediments up to 10,000 ft thick (Mabey, 1960). The sediments consist of a series of unconsolidated alluvial deposits interbedded with a thick layer of lacustrine deposits. These deposits are buried beneath as much as $800 \mathrm{ft}$ of alluvium near the southern limit of the Antelope Valley, but are exposed at land surface to the north near Rogers Lake (fig. 2B). The aquifer system in the Antelope Valley consists of two alluvial aquifers, the principal aquifer and the deep aquifer (Londquist and others, 1993). Both aquifers consist of interbedded heterogeneous mixtures of gravel, sand, and silt. The principal aquifer overlies lacustrine clay deposits that extend over most of the Antelope Valley south and west of Rogers Lake. The deep aquifer underlies the lacustrine clay deposits and extends beneath Rogers Lake and to the north. For this study, only the main urban area of the Antelope Valley that was within about $9,840 \mathrm{ft}(3 \mathrm{~km})$ of a public-supply well was evaluated. In this report, this area is referred to as the Antelope Valley Basin (fig. 2B). 


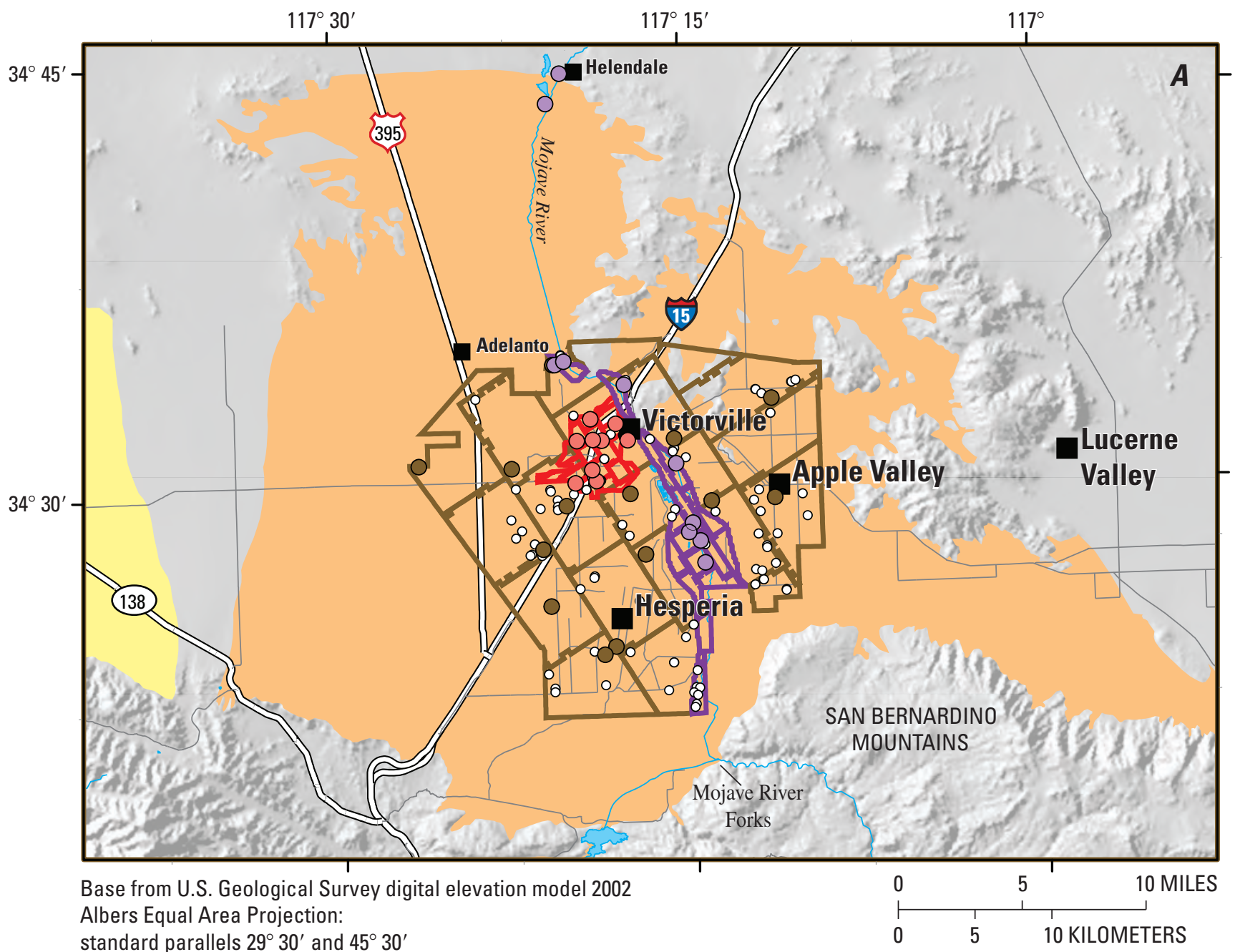

central meridian $-120^{\circ}$

\begin{tabular}{|c|c|}
\hline & EXPLANATION \\
\hline & Mojave River Ground-Water Basin \\
\hline & Antelope Valley Ground-Water Basin \\
\hline & Consolidated rock \\
\hline & $\begin{array}{l}\text { Sewered grid cells of Mojave River California Aquifer Susceptibility (MJSCAS) study } \\
\text { Sampled wells }\end{array}$ \\
\hline & $\begin{array}{l}\text { Floodplain grid cells of Mojave River California Aquifer Susceptibility (MJFCAS) study } \\
\text { O Sampled wells }\end{array}$ \\
\hline & $\begin{array}{l}\text { Regional grid cells Mojave River California Aquifer Susceptibility (MJRCAS) study } \\
\text { Sampled wells }\end{array}$ \\
\hline 0 & Other existing wells \\
\hline
\end{tabular}

Figure 2. Location of all existing and sampled wells in the (A) Mojave River and the (B) Antelope Valley Basins, California. 


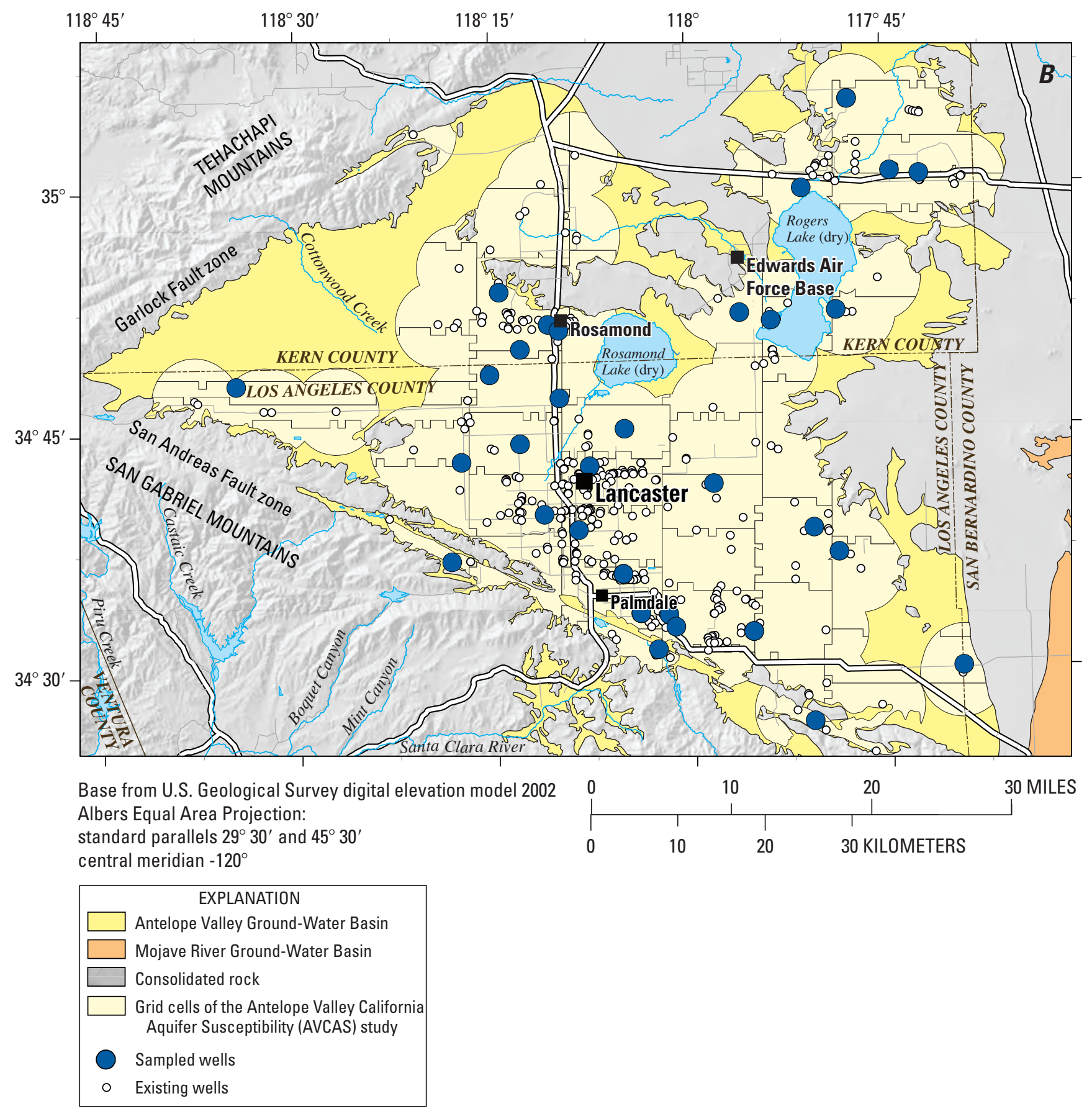

Figure 2. Continued. 


\section{Methods of Study}

VOC data were evaluated in conjunction with tritium data to determine the potential correlation of ground-water quality to aquifer type, depth to top of perforations, and land use within 1,640 $\mathrm{ft}(500 \mathrm{~m})$ of the well head in the Mojave River and the Antelope Valley Basins. Classes of VOCs (such as solvents) and detection frequencies for individual VOCs were compiled and compared to assess their distribution in the two ground-water basins. Potential explanatory variables were evaluated using detection frequencies for VOCs (in comparison with tritium detection frequencies).

\section{Well Selection}

Existing wells were selected for sampling using a gridbased program to produce equal-area random cells (Scott, 1990) within the boundary of the study area. The boundary for the Mojave River (MJCAS) Basin was initially defined as the ground-water basin boundary (fig. 2A) but, because of the lack of wells in outer-lying rural areas, this boundary was decreased to include only the boundaries of the major urban areas. The boundary was divided into three subareas: the floodplain aquifer (MJFCAS), the regional aquifer (MJRCAS), and the sewered subset of the regional aquifer (MJSCAS). Fifteen cells were generated in the grid-based program for each subarea. The floodplain aquifer covers $14 \mathrm{mi}^{2}$. The floodplain aquifer boundary used in this report is the same as that used by Izbicki and Michel (2004). As stated previously, the floodplain aquifer is recharged by surface-water infiltration along the Mojave River, the source of which is runoff from snowmelt and precipitation in the San Bernardino Mountains. The regional aquifer covers $162 \mathrm{mi}^{2}$ and receives limited recharge that infiltrates the thick unsaturated zone (as much as 1,000 ft thick) near the mountain front. The sewered subset of the regional aquifer covers $8 \mathrm{mi}^{2}$ and may receive recharge from leaking sewer pipes in this area. This sewered area differs slightly from that shown by Stamos and others (2001), which included not only the large sewered area shown here but also the smaller sewered areas. These three grids were considered representative of the MJCAS and were area-weighted averaged to provide a calculated detection frequency for the MJCAS.

The boundary for the Antelope Valley CAS (AVCAS) Basin was initially defined using the outline of the alluvial deposits identified by Leighton and Phillips (2003) and was later modified to include only the area that was within a 9,840 $\mathrm{ft}(3 \mathrm{~km})$ buffer around public-supply wells (fig. 2B). Forty cells were generated for the AVCAS Basin.
The cells in each study basin served as target areas for well selection for ground-water sampling. Suitable wells were chosen from an inventory of all wells obtained from the USGS Ground-Water Site Inventory (GWSI) and from information provided by the water purveyors for the Upper Mojave River and the Antelope Valley Basins. Wells were randomly selected from each cell to be statistically representative of the zone of ground water tapped by most of the public-supply wells in the area. The randomly selected wells were then ranked on the basis of the total number of wells chosen for a particular cell. Because the wells were randomly selected and geographically distributed, it was possible to look at any water-quality trends between the ground-water basins.

\section{Sample Collection}

Ground-water samples were collected during June 3 through 7, 2002, from 33 wells in the Mojave River Basin in the Victorville area and during September through October 2002 from 32 wells in the Antelope Valley Basin (table 1). In the Mojave River Basin, 9 wells were sampled in the floodplain aquifer, 15 were sampled in the regional aquifer, and 9 were sampled in the sewered area. In the Antelope Valley Basin, 17 wells were from the principal aquifer and 7 were from the deep aquifer. Well locations are shown in figures $2 \mathrm{~A}$ and $2 B$. Each well was sampled for VOCs, stable isotopes, and tritium. The VOCs analyzed in each sample collected for this study, and its predominant source or use, are listed in table 2.

Protocols, similar to those described in the USGS National Field Manual (Wilde and others, 1999) and used by the National Water-Quality Assessment (NAWQA) Program (Koterba and others, 1995; Koterba, 1998), were implemented in this study to eliminate sample contamination due to airborne contamination and (or) cross contamination between wells. These procedures ensured that a representative sample of ground water was taken at each site. Each well was pumped at least 20 minutes prior to sampling in order to purge a minimum of three casing volumes and to allow field waterquality measurements to stabilize. All samples were unfiltered and collected before any type of chemical treatment, such as chlorination, of the well water. One of two types of sampler material, high-purity tygon tubing or copper tubing, were used for the VOC sample collection. Although current protocol discourages the use of tygon tubing for the collection of VOC samples, high-purity tygon tubing is plasticizer free and was determined appropriate for this sampling. All samplers were cleaned prior to being taken into the field using similar procedures used by the NAWQA Program (Koterba and others, 1995). 


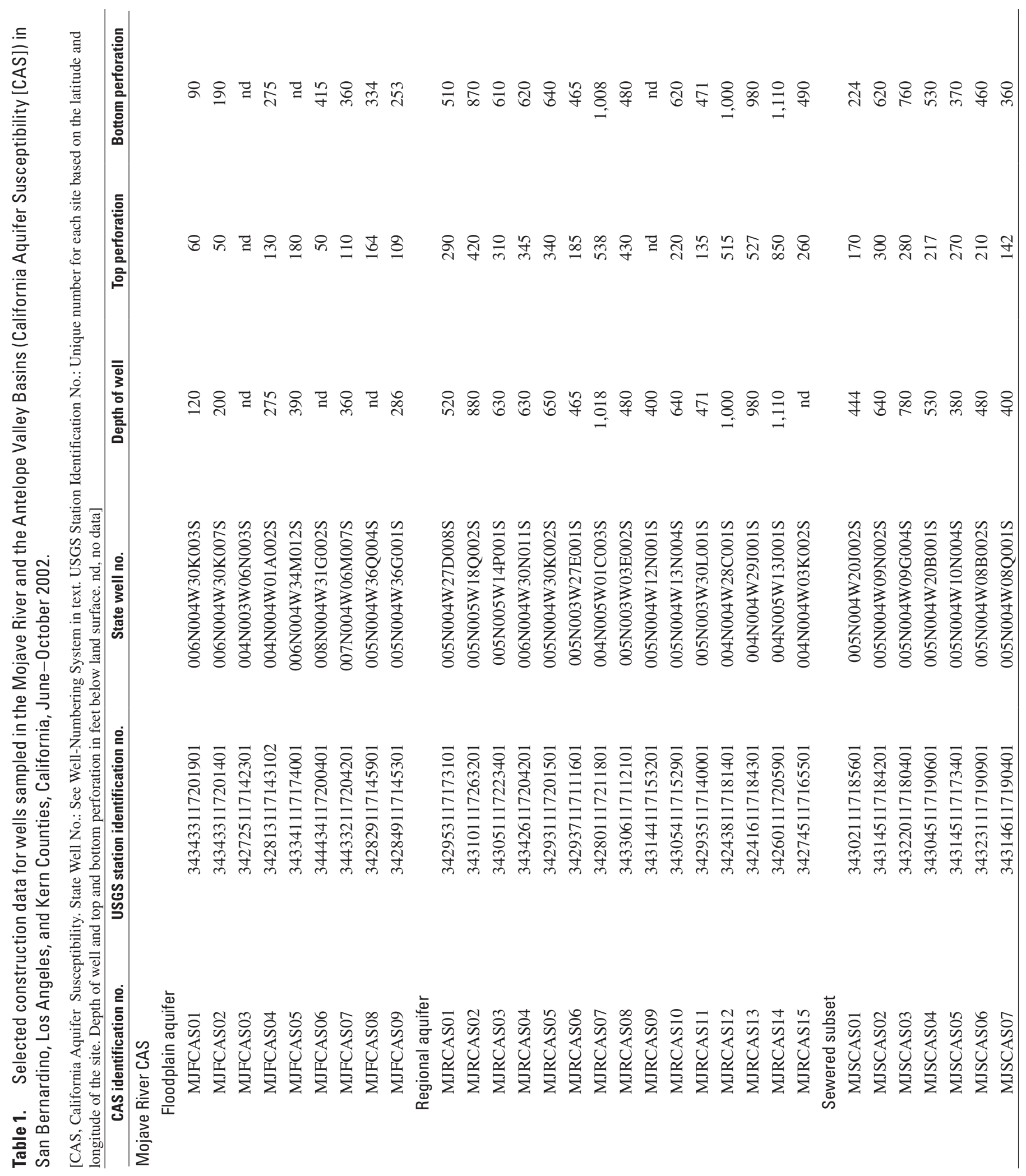




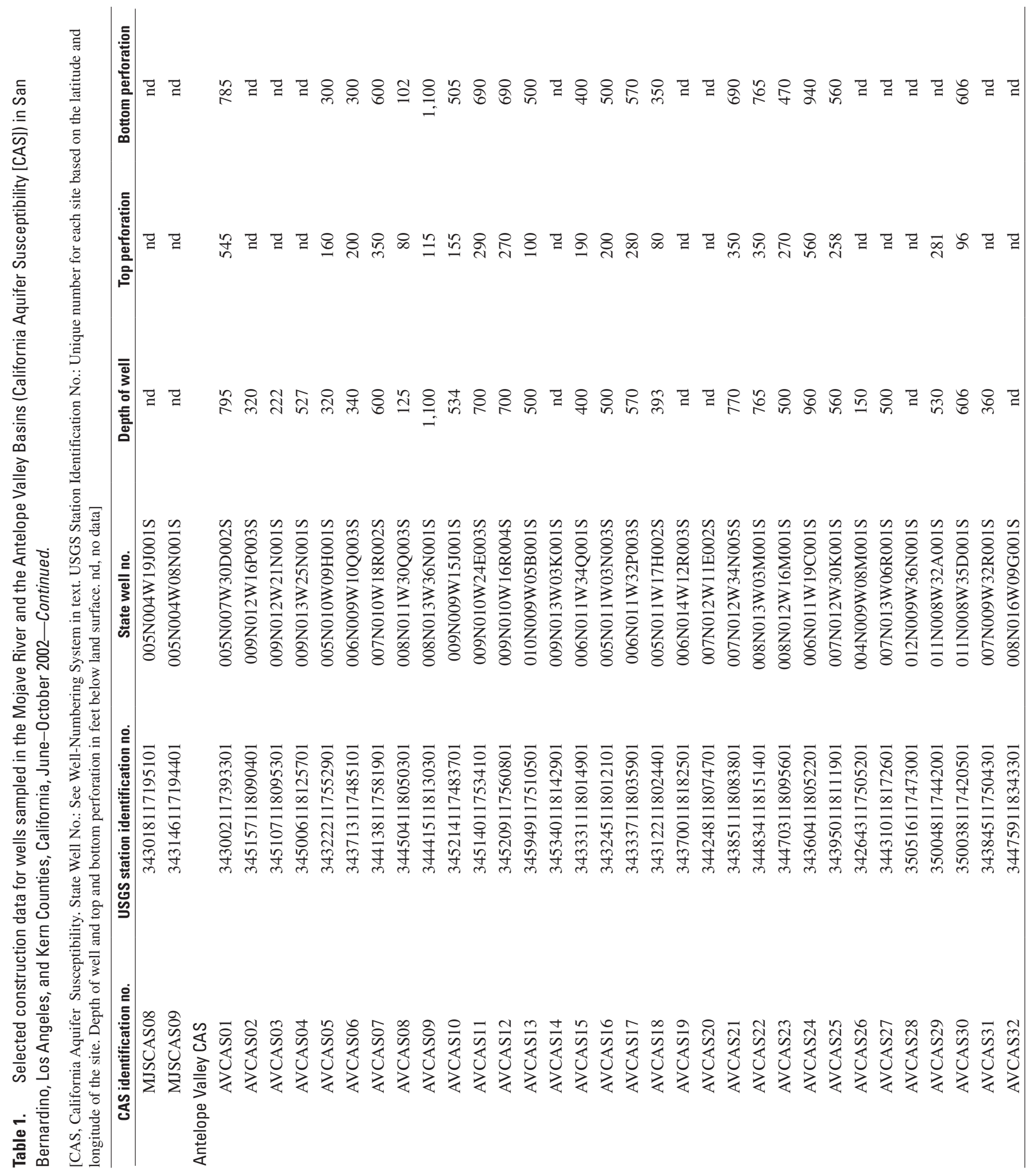


Table 2. Volatile organic compounds and primary use or source analyzed for in this study.

[VOC, volatile organic compound]

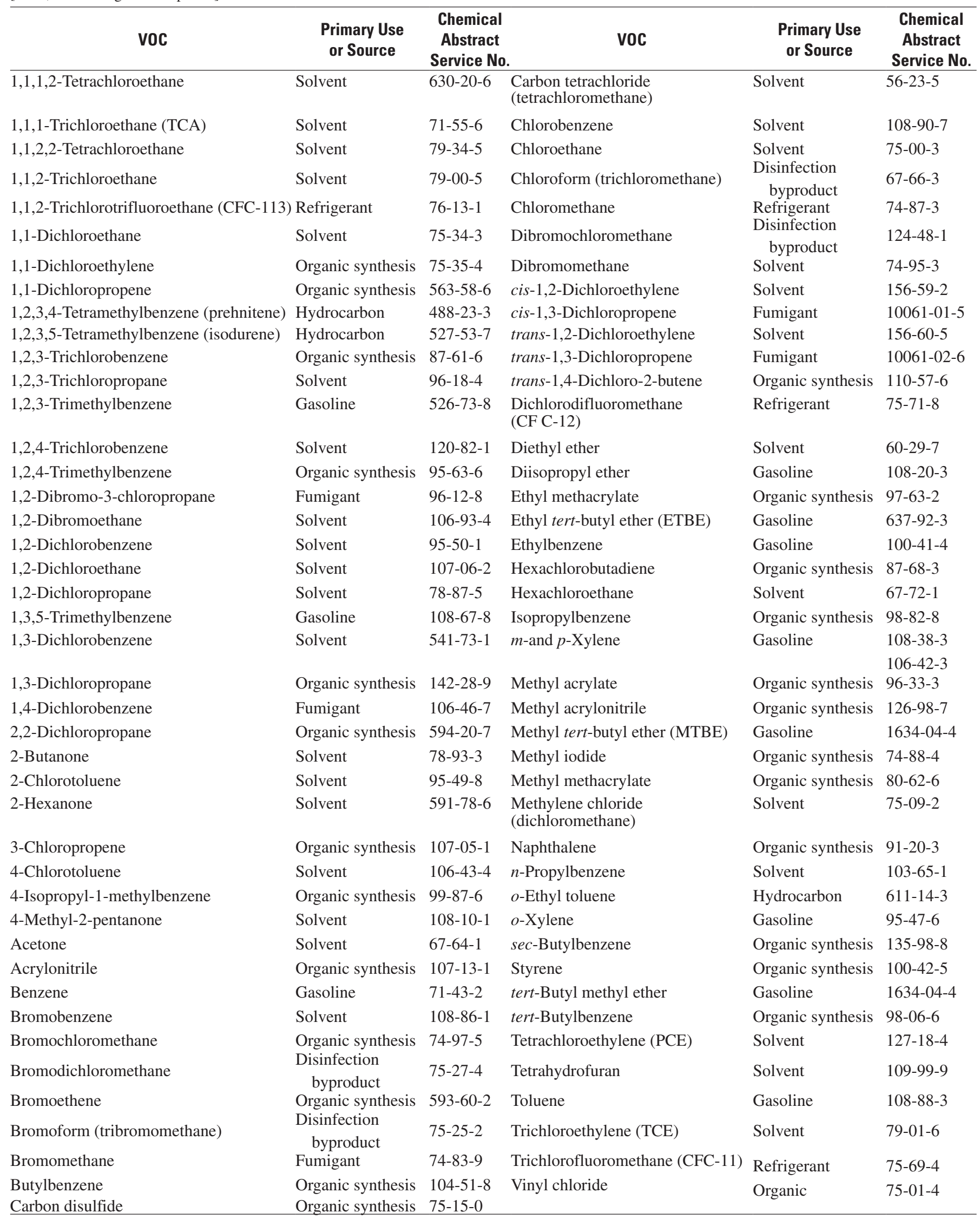


VOC samples were collected in 40-mL sample vials that were purged of three vial volumes and then bottom-filled so as not to leave any headspace. Hydrochloric acid was then added one drop at a time to the sample until the $\mathrm{pH}$ decreased to 2 or less. The sample bottles were put on ice and shipped to the USGS National Water-Quality Laboratory (NWQL) in Denver, Colorado, for analysis. Samples for stable isotopes of water were collected in 60-mL clear glass bottles filled with unfiltered water and capped; caps were secured using electrical tape to prevent leakage and evaporation. Tritium samples were collected by filling 1-liter amber bottles with unfiltered water, closed using caps with a conical insert and secured using electrical tape. These samples were analyzed by Lawrence Livermore National Laboratory in Livermore, California. VOCs, stable isotopes, and tritium concentrations were determined by analytical methods similar to those used by the NAWQA Program (Epstein and Mayeda, 1953; Coplen and others, 1991; Connor and others, 1998; Hudson and others, 2002).

\section{Determination and Use of Categorical Variables}

\section{Aquifer Type}

Wells were separated into categories based on aquifer type. The Mojave River Basin contains two aquifer types (the floodplain and the regional aquifer) that were divided into three subareas: the floodplain aquifer, the regional aquifer, and the sewered subset of the regional aquifer. As previously stated, the floodplain aquifer underlies the Mojave River floodplain and consists of permeable recent river deposits that were recharged by surface-water infiltration during snowmelt and precipitation runoff from the San Bernardino Mountains. Because there is very little precipitation in the study area itself, infiltration from precipitation and resulting urban runoff is minimal. The regional aquifer underlies and surrounds the floodplain aquifer and consists of unconsolidated older alluvium from the ancestral Mojave River and of undifferentiated alluvium that receives limited recharge from infiltration through the thick unsaturated zone. The sewered subset of the regional aquifer is a portion of the regional aquifer that may receive recharge from leaking sewer lines. These three areas were considered to be representative of the MJCAS Basin. Information on the depth and areal extent of these aquifer types were obtained from Stamos and others (2001).

The Antelope Valley Basin consists of two aquifer types: the principal aquifer and the deep aquifer. As previously stated, the principal aquifer overlies lacustrine clay deposits that extend over most of the valley south and west of Rogers Lake. The deep aquifer underlies the lacustrine clay beds and extends beneath Rogers Lake and to the north. Information on the depth and areal extent of these aquifer types were obtained from Londquist and others (1993) and Leighton and Phillips (2003). Seventeen of the wells sampled tap the principal aquifer and 7 tap the deep aquifer.

\section{Well Depth}

Wells were divided into two depth categories, shallow and deep, depending on the depth to the top, uppermost perforation. Shallow and deep categories were determined by the median depth to the top perforation for each study area. Wells having a depth less than the median value were categorized as shallow, and wells having a depth greater than the median value were categorized as deep. Wells for which there was no depth or perforation information (4 of 33 wells in MJCAS Basin; 11 of 32 wells in AVCAS Basin) were not used in the analysis. Depth and perforation information was compiled from water purveyors in the Mojave River and the Antelope Valley Basins, the USGS GWSI database, and the California Department of Water Resources.

\section{Land Use}

To determine the land-use category and the degree of urbanization in each study area, a 1,640 ft (500 m) circular buffer was identified around each public-supply well within which the percentages of land-use types (for example, urban, agricultural, or undeveloped) were calculated. The category was based on the predominant land use within each well's buffer area (Koterba, 1998). Wells were categorized either as high urban land use or low urban land use on the basis of the median percentage of urban land use for all the buffered area in a particular basin. Wells that had urban land-use percentages that were higher than the median percentage were classified as high urban land use; wells that had urban land-use percentages that were less than the median percentage were classified as low urban land use. Land-use data were obtained from the U.S. Geological Survey (2003). The land-use data consists of historical land-use and land-cover classification data that primarily were based on the manual interpretation of 1970s and 1980s aerial photography. It is unknown if these data have been field checked.

\section{Tritium Concentrations in Ground Water}

On the basis of tritium concentrations, water samples from wells were divided into two age categories: young and old. The age of a ground-water sample was determined on the basis of the tritium concentration in that sample. Ground-water samples were interpreted as young (water recharged after 1952) or containing young water if tritium concentrations in the samples were greater than or equal to the detection limit of 1 picocurie per liter ( $\mathrm{pCi} / \mathrm{L})$. Ground-water samples were interpreted as old (water recharged prior to 1952) if tritium concentrations in the samples were less than $1 \mathrm{pCi} / \mathrm{L}$. This threshold has been used in several previous studies (Wright and others, 2004; Hamlin and Belitz, in press) and is less than the threshold of $3.19 \mathrm{pCi} / \mathrm{L}$ (1 tritium unit) used by the U.S. Environmental Protection Agency (USEPA) to identify young water (Walsh, 1992). 
The actual age of the ground water (time since recharge) was also estimated using the tritium and helium-3 $\left({ }^{3} \mathrm{He}\right.$, its daughter product) data. The ages were calculated assuming a conservative treatment of radiogenic ${ }^{3} \mathrm{He}$ and, therefore, are older than if it was assumed no radiogenic ${ }^{3} \mathrm{He}$ was present. Apparent ages were also estimated using radiogenic helium-4 $\left({ }^{4} \mathrm{He}\right)$ data assuming an accumulation rate of $5 \times 10^{-11} \mathrm{~cm}^{3} \mathrm{~S} \mathrm{TP} / \mathrm{g} / \mathrm{yr}$. It should be noted that radiogenic ${ }^{4} \mathrm{He}$ ages are very uncertain when calculated using a global accumulation rate. The accumulation rate used in this study is the geometric mean of ${ }^{4} \mathrm{He}$ accumulation rates estimated by Kulongoski and others (2003) for this area.

\section{Quality-Control Data Analyses}

To ensure that water-quality data are accurate and assure that representative water-quality data are collected, collection of quality-control samples is required for all water-quality studies. Quality-control (QC) samples were collected to identify, quantify, and document bias and variability in data resulting from sample collection, processing, shipping, and handling (Wilde and others, 1999).

\section{Surrogate Data Analysis}

To evaluate the ability of the analytical method to detect target analytes in each sample and to determine whether matrix interference (by the sample water chemistry affecting the VOC analysis) occurred, surrogates were added to all VOC samples at the NWQL before analysis. Surrogates are compounds that behave similarly to VOC analytes and are not typically detected in ground water. For this study, three surrogates (1,2-dichloroethane-d4, toluene-d8, and $p$-bromofluorobenzene) were added to all VOC samples at the NWQL. Surrogate recoveries are reported as percent with acceptable limits ranging from 70 to 130 percent; recoveries outside of acceptable limits may indicate matrix interference or sample analysis problems (Connor and others, 1998).

Median recoveries for all three surrogates in all samples collected for the Mojave River and the Antelope Valley Basins were within the acceptable limit range of 70 to 130 percent. Surrogate recoveries for 1,2-dichloroethane-d4, toluene-d8, and $p$-bromofluorobenzene ranged from 100 to 117 percent, 98 to 104 percent, and 84 to 115 percent, respectively, for the samples from the Mojave River Basin, and 112 to 129 percent, 95 to 103 percent, and 80 to 91 percent, respectively, for the samples from the Antelope Valley Basin. No modifications were made to the data based on surrogate data.

\section{Blank Data Analysis}

To evaluate the potential for sample contamination introduced during sample collection, processing, transportation, and laboratory analysis, blank samples were collected at 10 percent of the well sites using specially prepared organic-free water that was certified to contain less than the laboratory reporting level (LRL) of the selected VOCs. The blank samples were then analyzed using the same methods used to analyze the ground-water samples. For this study, two types of blank samples (field and source solution) were collected. Field blanks were collected to measure any sample contamination to the sample from any aspect of the sampling process. Source-solution blanks were collected to verify that the blank water used for the field blanks had no concentrations of VOCs detectable at the LRL.

The field blank samples were collected by pouring organic-free water, from its original container, through clean sampling equipment into the sample bottle, and then processing and analyzing the blank sample using the same method as that used for the ground-water samples. Concentrations of VOCs detected in field blanks were compared with concentrations detected in the ground-water samples from the same study area. Source-solution blanks were collected at the sampling location by pouring blank water directly into sample bottles; the blanks were then stored, shipped, and analyzed in the same manner as the ground-water samples.

A VOC in a ground-water sample was considered to be a potential QC concern if it was detected in one or more field blanks and in the ground-water samples. If the VOC was determined to be a potential QC concern, the concentration of that VOC in the field blank was compared with the concentration detected in the associated source-solution blank. If the VOC detected in the field blank was detected at the same or lower concentration in the source solution, the VOC was not a QC concern. If the VOC was not detected in the source solution blank, the concentration in the field blank was compared with the concentration in the ground-water sample collected after that field blank. The same sampling equipment was used to collect the field blank and a paired ground-water sample.

Field blank detections that are equal to or higher than the paired ground-water sample detection indicate possible sample contamination. If sample contamination was identified, all ground-water samples and field blanks were evaluated for evidence of sample contamination for that specific VOC. Groundwater samples that had a VOC detection that was lower than or equal to the highest field blank concentration was counted as a non-detection, and a value less than the LRL was substituted for the measured concentration. If the paired ground-water samples had a VOC detection that was higher than that for the field blank, they were E-coded (coded as estimated) in the USGS database to indicate that the concentrations may not be accurate (owing to sample contamination as indicated by the concentration detected in the field blank), but that the VOC was believed present in the ground water. The E-coded data were counted as having VOC detections.

Fifteen blank samples were collected for this study. Eight of the 15 blank samples were collected in the Mojave River Basin and 7 in the Antelope Valley Basin. Of the 15 samples, 8 were field blanks and 7 were source-solution blanks (table 3). 
1,2-dichloropropane and carbon disulfide were detected in 2 of the 15 blank samples (table 3). 1,2 dichloropropane was detected in both the field and source solution blanks at one well in the Mojave River Basin. The concentration in the source solution blank was about equal to the concentration in the field blank; and there was no detection in the paired ground-water sample; thus, this VOC was determined not to be a QC concern. Carbon disulfide was detected in two field blanks but not in the source solution or the associated paired ground-water sample; this VOC also was determined not to be a QC concern.

Methylbenzene (toluene) was detected in 13 of the 15 blank samples from the Mojave River and the Antelope Valley Basins. Concentrations in the blank samples ranged from 0.01 to $0.06 \mu \mathrm{g} / \mathrm{L}$ in samples from the Mojave River Basin and 0.01 to $1.34 \mu \mathrm{g} / \mathrm{L}$ in samples from the Antelope Valley Basin (table 3). Although toluene was the most frequently detected compound in both areas, it is believed that the detection of this analyte resulted from contamination during sample collection, processing, transportation, and (or) laboratory analysis, and in all cases was not considered a detection for this analysis.

In the Mojave River Basin, toluene was detected in all the field and source-solution blank samples. Except for field blank QMJCAS05, all field blanks had concentrations of toluene lower than that in the source-solution blanks (QMJCAS02, 04, and 08) (table 3). Toluene was detected in 2 of the 4 paired ground-water samples (MJRCAS06 and -15). The toluene concentration in one of the paired ground-water samples (MJRCAS15) was lower than that in the paired field blank (QMJCAS08), indicating that the toluene in the groundwater samples was at least partly due to sample contamination. Because concentrations in the ground-water samples were lower than the highest field blank concentration (about 0.03 $\mu \mathrm{g} / \mathrm{L})$, all toluene detections in the 23 Mojave River Basin ground-water samples, which ranged from 0.009 to $0.02 \mu \mathrm{g} / \mathrm{L}$, were counted as non-detections.

Table 3. Summary of quality-control data for volatile organic compounds (VOC) detected in field blanks and associated source-solution blanks collected during the Mojave River and the Antelope Valley Basin studies, San Bernardino, Los Angeles, and Kern Counties, California, 2002.

[Number of wells in study, 15. CAS, California Aquifer Susceptibility. Number in parentheses is the data parameter code, a fivedigit code used in the U.S. Geological Survey computerized data system, National Water Information System (NWIS), to uniquely identify a specific constituent or property. LRL, laboratory reporting limit; $\mu \mathrm{g} / \mathrm{L}$, microgram per liter; E, estimated; <, actual value is less than the value shown; no., number; —, less than LRL]

\begin{tabular}{|c|c|c|c|c|c|c|}
\hline $\begin{array}{c}\text { CAS } \\
\text { identification } \\
\text { no. }\end{array}$ & $\begin{array}{c}\text { Related CAS } \\
\text { identification } \\
\text { no. }\end{array}$ & $\begin{array}{l}\text { Sample } \\
\text { type }\end{array}$ & $\begin{array}{l}\text { Date of sampling } \\
\text { (month, day, year) }\end{array}$ & $\begin{array}{c}\text { 1,2-Dichloro- } \\
\text { propane } \\
(\mu \mathrm{g} / \mathrm{L}) \\
(34541)\end{array}$ & $\begin{array}{c}\text { Carbon } \\
\text { disulfide } \\
(\mu \mathrm{g} / \mathrm{L}) \\
(77041)\end{array}$ & $\begin{array}{c}\text { Methylbenzene } \\
\text { (Toluene) } \\
(\mu \mathrm{g} / \mathrm{L}) \\
(34010)\end{array}$ \\
\hline LRL & & & & $<0.029$ & $<0.07$ & $<0.05$ \\
\hline \multicolumn{7}{|l|}{ Mojave River CAS } \\
\hline QMJCAS01 & MJRCAS06 & Field Blank & 06/05/2002 & - & - & E0.03 \\
\hline QMJCAS02 & MJRCAS06 & Source Solution & 06/05/2002 & - & - & E0.06 \\
\hline QMJCAS03 & MRSCAS09 & Field Blank & 06/06/2002 & - & - & E0.02 \\
\hline QMJCAS04 & MRSCAS09 & Source Solution & 06/06/2002 & - & - & E0.05 \\
\hline QMJCAS05 & MJRCAS14 & Field Blank & 06/06/2002 & E0.02 & - & E0.01 \\
\hline QMJCAS06 & MJRCAS14 & Source Solution & 06/06/2002 & E0.02 & - & E0.01 \\
\hline QMJCAS07 & MJRCAS15 & Field Blank & 06/07/2002 & - & - & E0.01 \\
\hline QMJCAS08 & MJRCAS15 & Source Solution & 06/07/2002 & - & - & E0.04 \\
\hline \multicolumn{2}{|c|}{ Number of VOC detections } & & & 2 & 0 & 8 \\
\hline \multicolumn{7}{|l|}{ Antelope Valley CAS } \\
\hline QAVCAS01 & AVCAS05 & Field Blank & $09 / 24 / 2002$ & - & - & E0.02 \\
\hline QAVCAS02 & AVCAS05 & Source Solution & $09 / 24 / 2002$ & - & 一 & E0.02 \\
\hline QAVCAS03 & AVCAS17 & Field Blank & $09 / 26 / 2002$ & - & E0.03 & E0.24 \\
\hline QAVCAS04 & AVCAS17 & Source Solution & $09 / 26 / 2002$ & - & - & E0.01 \\
\hline QAVCAS05 & AVCAS24 & Field Blank & $10 / 21 / 2002$ & - & E0.02 & 1.34 \\
\hline QAVCAS06 & AVCAS24 & Source Solution & $10 / 21 / 2002$ & - & - & - \\
\hline QAVCAS07 & AVCAS28 & Field Blank & $10 / 23 / 2002$ & - & - & - \\
\hline \multicolumn{2}{|c|}{ Number of VOC detections } & & & 0 & 2 & 5 \\
\hline
\end{tabular}


In the Antelope Valley Basin, toluene was detected in 3 of the 4 field blanks (QAVCAS01, 03, and 05) and in 2 of the 3 source solution blanks (QAVCAS02 and 04). The field blank with the highest concentration (QAVCAS05) had no matching detection in the paired source solution blank (QAVCAS06) or in the paired ground-water sample (AVCAS24), indicating sample contamination. The detections in the ground-water samples from the Antelope Valley Basin decreased to 0 percent because all the detections of toluene in these samples, which ranged from 0.01 to $0.30 \mu \mathrm{g} / \mathrm{L}$, were lower than the highest field blank concentration of $1.34 \mu \mathrm{g} / \mathrm{L}$. These detections were counted as non-detections.

\section{Statistical Analysis}

Statistical analyses were used to evaluate the relation of explanatory factors, such as aquifer type, well depth, land use within 1,640 ft of the well head, or relative ground-water age, to the distribution and occurrence of VOCs. Data groups were compared to test for potential relations between explanatory factors and the number of detections of VOCs. Variations in the occurrence of compounds were compared by aquifer type for each study area. This analysis was further refined by evaluating the occurrence of compounds by well depth using the median value for each study area. Similar comparisons were done for VOCs in ground water relative to land use using median values of percentage urban development within 1,640 ft of the wellhead. Explanatory factors also were compared between the two study areas to ensure that the geographic variability in these factors did not account for observed relations.

Frequency-of-detection plots also were used to show the percentage of samples having detectable concentrations of VOC compounds. The number of VOCs detected were then evaluated in relation to aquifer type, land use within 1,640 ft of the well head, and well depth (where known) using similar methods. Additionally, data groupings or categories were compared using the Kruskal-Wallis and Wilcoxon tests to ensure that statistical relations between explanatory and response variables were not related to geographic variability of the explanatory variable. These tests evaluate the statistical significance of differences between categories of data (Ott, 1993). The Kruskal-Wallis rank was used to compare three explanatory categories (for example, aquifer type for the Mojave River samples) to determine if one category contained larger values than another. The Wilcoxon rank sum test compared two independent data categories to determine if one group contained larger values than the other. A probability $(\mathrm{P})$ value of 0.05 from these tests indicates a 95-percent confidence that the measured values were not the result of chance occurrence.

Box plots also were used to show the characteristics of the data set. The enclosed area of a box plot includes the values located between the first and third quartiles of the data set. The median value is identified by a solid line with a circle through the box. Whiskers extend from the box ends to identify the extreme values of the data set that are no more than 1.5 times the length of the interquartile range. Values beyond 1.5 times the inter-quartile range are outliers and are marked with a solid line that is not connected to the box (Venables and Ripley, 1999).

\section{Results}

This section presents the detection frequencies of any VOC, tritium, and specific class or use of VOCs. Detection frequencies of the VOCs were evaluated by compound and the relation between VOC occurrence and age of the ground water. Variations in aquifer type, well depth, and land use within 1,640 ft of the well head, and the occurrence of VOCs in the Mojave River and the Antelope Valley Basins also were evaluated to determine explanatory factors. Table 2 lists the VOC and VOC sources that were analyzed for in this study, and table 4 lists the concentrations of the VOC detections for samples collected from the Mojave River and Antelope Valley Basins. Table 5 lists the tritium and noble gas data, the calculated values of excess air, the apparent ages of ground water based on the tritium $/{ }^{3} \mathrm{He}$ and ${ }^{4} \mathrm{He}$ data, and the ground-water recharge temperatures.

\section{Detection Frequencies for VOCs, Tritium, and VOC Class}

Ground-water samples were collected from the Mojave River and Antelope Valley Basins, the floodplain and regional aquifers, and the sewered grids. Detection frequencies were plotted showing the percentage of samples from each area in which VOCs, tritium, and specific classes of VOCs were detected (fig. 3A, B). In general, the VOCs were detected slightly more often in the samples from the Antelope Valley Basin (34 percent) than in all the samples from the Mojave River Basin (area-weighted average of 28 percent). For the Mojave River Basin, VOCs were detected more frequently in the samples from the floodplain aquifer ( 44 percent) than in the samples from the regional aquifer (27 percent) and the sewered subset (22 percent). Tritium was detected more frequently in all the Mojave River Basin samples (30 percent) than in the Antelope Valley Basin samples (19 percent). Tritium in the Mojave River Basin was detected more frequently in the samples from the floodplain aquifer ( 89 percent) than in the samples from the regional aquifer ( 7 percent) and the sewered subset (11 percent). In general, most of the samples collected for this study contained old water, 70 percent and 81 percent of samples from the Mojave River Basin and the Antelope Valley Basin, respectively. These data show that neither basin has received much recent (since 1952) recharge. The Mojave River Basin receives more recharge than the Antelope Valley Basin because the floodplain aquifer is recharged directly from the Mojave River, which contains recent precipitation runoff. 
Table 4A. Summary of volatile organic compound (VOC) concentrations listed in order of detection frequency for wells sampled during 2002 in the floodplain aquifer in the Mojave River Basin California Aquifer Susceptibility (MJCAS) study, San Bernardino County, California.

[Number of wells in study area, 9. CAS, California Aquifer Susceptibility program. Percentage values are detection frequencies of VOC class. Number in parentheses is the data parameter code, a five-digit code used in the U.S. Geological Survey computerized data system, National Water Information System (NWIS), to uniquely identify a specific constituent or property. THM, trihalomethane; LRL, laboratory reporting limit; $\mu \mathrm{g} / \mathrm{L}$, microgram per liter; E, estimated by laboratory; <, actual value is less than the value shown; no., number; - , not detected; number in bold, concentration measured above reporting limit; number in italics, concentration measured below reporting limit]

\begin{tabular}{|c|c|c|c|c|c|c|}
\hline \multirow[b]{2}{*}{$\begin{array}{c}\text { CAS } \\
\text { identification } \\
\text { no. }\end{array}$} & \multirow[b]{2}{*}{$\begin{array}{l}\text { Date of sampling } \\
\text { (day, month, year) }\end{array}$} & \multirow[b]{2}{*}{$\begin{array}{l}\text { Number of } \\
\text { VOC } \\
\text { detections }\end{array}$} & \multicolumn{2}{|c|}{ THM (22 percent) } & \multicolumn{2}{|c|}{ Solvent (22 percent) } \\
\hline & & & $\begin{array}{c}\text { Tribromomethane } \\
\text { (Bromoform), } \\
\mu \mathrm{g} / \mathrm{L} \\
(32104)\end{array}$ & $\begin{array}{c}\text { Trichloromethane } \\
\text { (Chloroform), } \\
\mu \mathrm{g} / \mathrm{L} \\
(32106)\end{array}$ & $\begin{array}{c}\text { Tetrachloroethylene } \\
\text { (PCE), } \\
\mu \mathrm{g} / \mathrm{L} \\
(34475)\end{array}$ & $\begin{array}{c}\text { 1,1,1-Trichloroethane } \\
\text { (TCA), } \\
\mu \mathrm{g} / \mathrm{L} \\
(34506)\end{array}$ \\
\hline LRL & & & $<0.06$ & $<0.024$ & $<0.027$ & $<0.032$ \\
\hline MJFCAS01 & 06/04/2002 & 1 & - & 0.11 & - & - \\
\hline MJFCAS05 & $06 / 06 / 2002$ & 1 & - & - & E 0.01 & - \\
\hline MJFCAS08 & $06 / 07 / 2002$ & 1 & - & - & - & E 0.01 \\
\hline \multicolumn{2}{|c|}{ Wells with a VOC detection } & 4 & 1 & 1 & 1 & 1 \\
\hline \multicolumn{2}{|c|}{ Detection frequency (percent) } & 44 & 11 & 11 & 11 & 11 \\
\hline
\end{tabular}

Trihalomethanes (THM) were detected less frequently in all the Mojave River Basin samples (15 percent) than in the Antelope Valley Basin samples (31 percent). In the Mojave River Basin, THMs were detected more frequently in the samples from the floodplain aquifer (22 percent) than in the samples from the regional aquifer (20 percent) and were not detected in the sewered subset. Solvents (for example, tetrachloroethylene [PCE] and trichloroethylene [TCE]; complete list shown in table 2) were detected more frequently in all the Mojave River Basin samples (21 percent) than in the Antelope Valley Basin samples (13 percent). In the Mojave River Basin, solvents were detected less frequently in the samples from the floodplain aquifer (22 percent) and the sewered subset (22 percent) than in the samples from the regional aquifer (27 percent). Benzene, toluene, ethylbenzene, and xylene (BTEX) were not detected in samples from the Mojave River or the Antelope Valley Basins. Methyl tert-butyl ether (MTBE) was detected in two Mojave River Basin samples and one Antelope Valley Basin sample (3 percent in each area). In the Mojave River Basin samples, based on the detection by area, MTBE was detected more frequently in the samples from the sewered subset (11 percent) than in the samples from the regional aquifer (7 percent); it was not detected in the samples from the floodplain aquifer.

THMs, a by-product from the disinfection of drinking and wastewater, were the most frequently detected class of VOC. In the Antelope Valley, Fram and others (2003) documented the formation and fate of THMs during an aquifer injection, storage, and recovery study at Lancaster; so the presence of THMs are not unexpected. Solvents, with uses ranging from metal degreasing to dry cleaning, would be expected to be detected more frequently in commercial and residential urban areas, as was the case in the Mojave River Basin. MTBE was less frequently detected than THMs and solvents in both study areas, probably because it has only recently (since the early 1990s) been used as an additive to gasoline in California (Grady and Casey, 2000). The data also show that, except in the Mojave River floodplain aquifer, tritium was not detected as frequently as VOCs, suggesting that tritium need not be present in order for VOCs to be present in these desert areas.

\section{Detection Frequency of VOC by Compound}

Detection frequencies of VOCs were plotted showing the percentage of samples containing each individual VOC to determine the compounds detected most frequently in the Mojave River and the Antelope Valley Basins (fig. 4). Seventeen different VOCs were detected in the two basins. Because so few individual VOC compounds were detected during this study, compounds detected in at least 10 percent of the wells sampled were considered frequently detected. Fourteen of the 17 VOCs were detected in ground-water samples from the Mojave River Basin; only chloroform was considered frequently detected. Eleven of the 17 VOCs were detected in the Antelope Valley ground-water samples and only 2 of these 11 (chloroform and tetrachloroethylene, or PCE) were considered frequently detected.

The only compound frequently detected in both the Mojave River and the Antelope Valley Basins was chloroform. Chloroform has been used in the production of the refrigerant hydrochlorofluorocarbon, in the production of plastics (for example, vinyl chloride), and as an industrial solvent (National Safety Council, 2004). Chloroform also is a common drinkingwater contaminant because it forms during the chlorination of drinking and reclaimed water (Grady and Casey, 2000). 


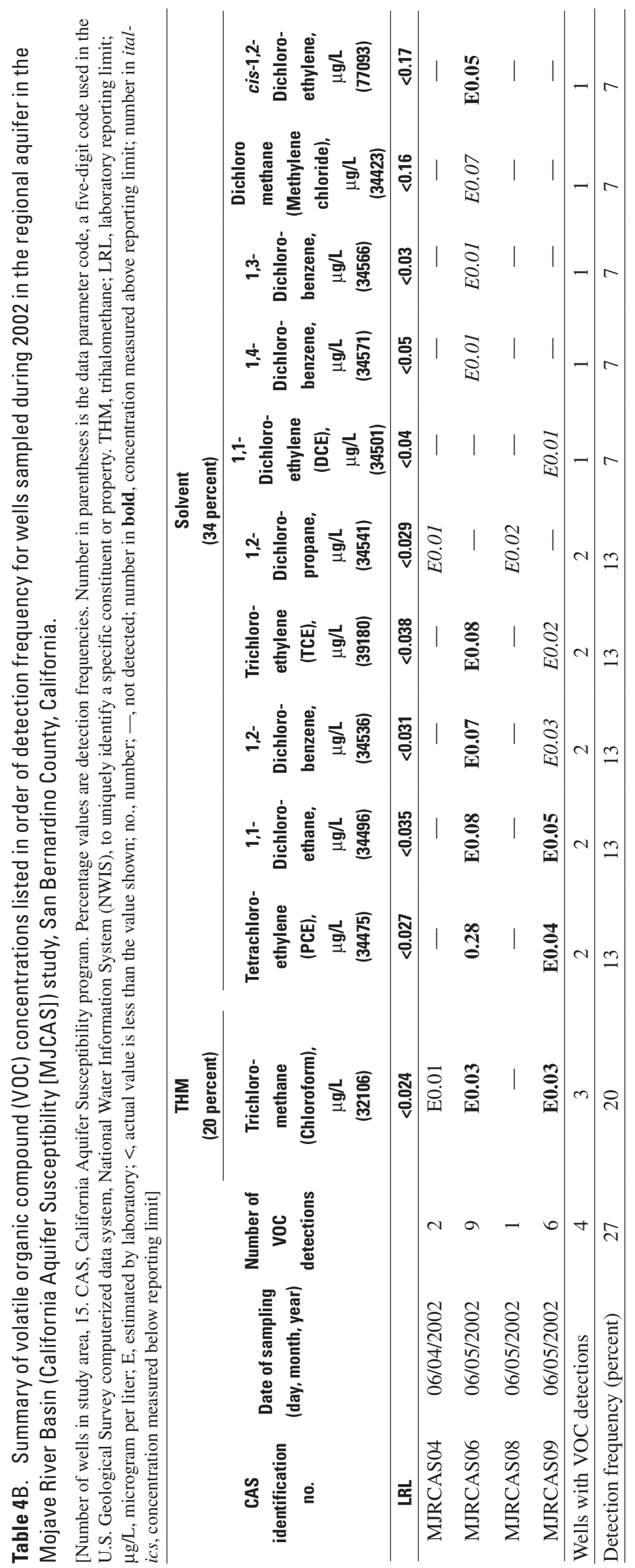


Table 4C. Summary of volatile organic compound (VOC) concentrations listed in order of detection frequency for wells sampled during 2002 in the sewered subset of the regional aquifer in the Mojave River Basin (California Aquifer Susceptibility [MJCAS]) study, San Bernardino County, California.

[Number of wells in study area, 9. CAS, California Aquifer Susceptibility program. Percentage values are detection frequencies. Number in parentheses is the data parameter code, a five-digit code used in the U.S. Geological Survey computerized data system, National Water Information System (NWIS), to uniquely identify a specific constituent or property. THM, trihalomethane; LRL, laboratory reporting limit; $\mu \mathrm{g} / \mathrm{L}$, microgram per liter; E, estimated by laboratory; <, actual value is less than the value shown; no., number; —, not detected; number in bold, concentration measured above reporting limit]

\begin{tabular}{|c|c|c|c|c|c|}
\hline \multirow[b]{2}{*}{$\begin{array}{c}\text { CAS } \\
\text { identification } \\
\text { no. }\end{array}$} & \multirow[b]{2}{*}{$\begin{array}{l}\text { Date of sampling } \\
\text { (day, month, year) }\end{array}$} & \multirow[b]{2}{*}{$\begin{array}{l}\text { Number of } \\
\text { VOC } \\
\text { detections }\end{array}$} & \multicolumn{2}{|c|}{ Solvent (22 percent) } & \multirow[b]{2}{*}{$\begin{array}{c}\text { Gasoline (11 percent) } \\
\text { Methyl tert-butyl ether } \\
\text { (MTBE) } \\
\mu \mathrm{g} / \mathrm{L} \\
\text { (78032) }\end{array}$} \\
\hline & & & $\begin{array}{c}\text { 1,1-Dichloroethylene } \\
\text { (DCE), } \\
\mu \mathrm{g} / \mathrm{L} \\
(34501)\end{array}$ & $\begin{array}{c}\text { 1,2-Dichloro } \\
\text { propane, } \\
\mu \mathrm{g} / \mathrm{L} \\
(34541)\end{array}$ & \\
\hline LRL & & & $<0.04$ & $<0.029$ & $<0.17$ \\
\hline MJSCAS07 & $06 / 03 / 2002$ & 2 & E0.04 & - & 0.73 \\
\hline MJSCAS08 & 06/04/2002 & 1 & - & E0.03 & - \\
\hline \multicolumn{2}{|c|}{ Wells with a VOC detection } & 2 & 1 & 1 & 1 \\
\hline \multicolumn{2}{|c|}{ Detection frequency (percent) } & 22 & 11 & 11 & 11 \\
\hline
\end{tabular}

PCE, a solvent, also was detected frequently in the ground-water samples from the Antelope Valley Basin. PCE is a commonly used solvent (Stackelberg and others, 2000) and has been frequently detected in ground water in other NAWQA study areas in California (Hamlin and others, 2002; Dawson and others, 2003).

\section{VOC Occurrence by Ground-Water Age}

Bar graphs and box plots were generated for both the Mojave River and the Antelope Valley Basins to evaluate the occurrence of recent ground-water recharge and VOC detection. These graphs show the detection frequency and the number of VOCs detected for samples that were interpreted to contain old and young water in the Mojave River and Antelope Valley Basins (fig. 5A-C).

Figure 5A shows the detection frequency of VOCs in young and old ground water in the Mojave River Basin. VOCs were detected more often in young water (40 percent) than in old water ( 26 percent). It should be noted, however, that VOCs were not detected in 60 percent of the samples of young ground water and 74 percent of the samples of old ground water from the Mojave River Basin. The number of VOCs detected in the samples of old water does not differ statistically (p-value $=0.716$, Wilcoxon Rank) from the number of VOCs detected in the samples of young water (fig. 5B). The median number of VOCs detected in both young and old ground water from the Mojave River Basin was zero. Thus, at least 50 percent of the samples of both the young and old water contained no VOCs (fig. 5B). The remainder contained at least one VOC.
Figure 5A also shows the detection frequency of VOCs in young and old water in the Antelope Valley Basin. VOCs were detected more often in young water (67 percent) than in old water (27 percent). However, VOCs were not detected in 33 percent of the samples of young water and in 73 percent of the samples of old water from the Antelope Valley Basin. The number of VOCs detected in old water from the Antelope Valley Basin differs ( $\mathrm{p}$-value $=0.1258$, Wilcoxon Rank) from the number of VOCs detected in young water (fig. 5C). The median number of VOCs detected was zero in the old water from the Antelope Valley Basin. The median number of VOCs detected was less than 2 in the young water from the Antelope Valley Basin. At least 50 percent of the samples of old water contained no VOCs, and the remainder contained at least one VOC. Likewise, 50 percent of the samples of young water contained one or no VOCs. The remainder contained more than 1 VOC.

The results suggest that younger water in the Mojave River and the Antelope Valley Basins may be more likely to be contaminated than older water because VOCs were detected more frequently in young water than in old water. However, VOCs were not detected in 60 percent of the samples of young water from the Mojave River Basin nor in 33 percent of the samples from the Antelope Valley Basin. VOCs also were not detected in 74 percent of the samples of old water from the Mojave River Basin and in 73 percent of the samples from the Antelope Valley Basin. Thus, these occurrences suggest that the presence of tritium (indicating young water) is not necessarily an indicator of aquifer susceptibility to contaminants in these areas. 


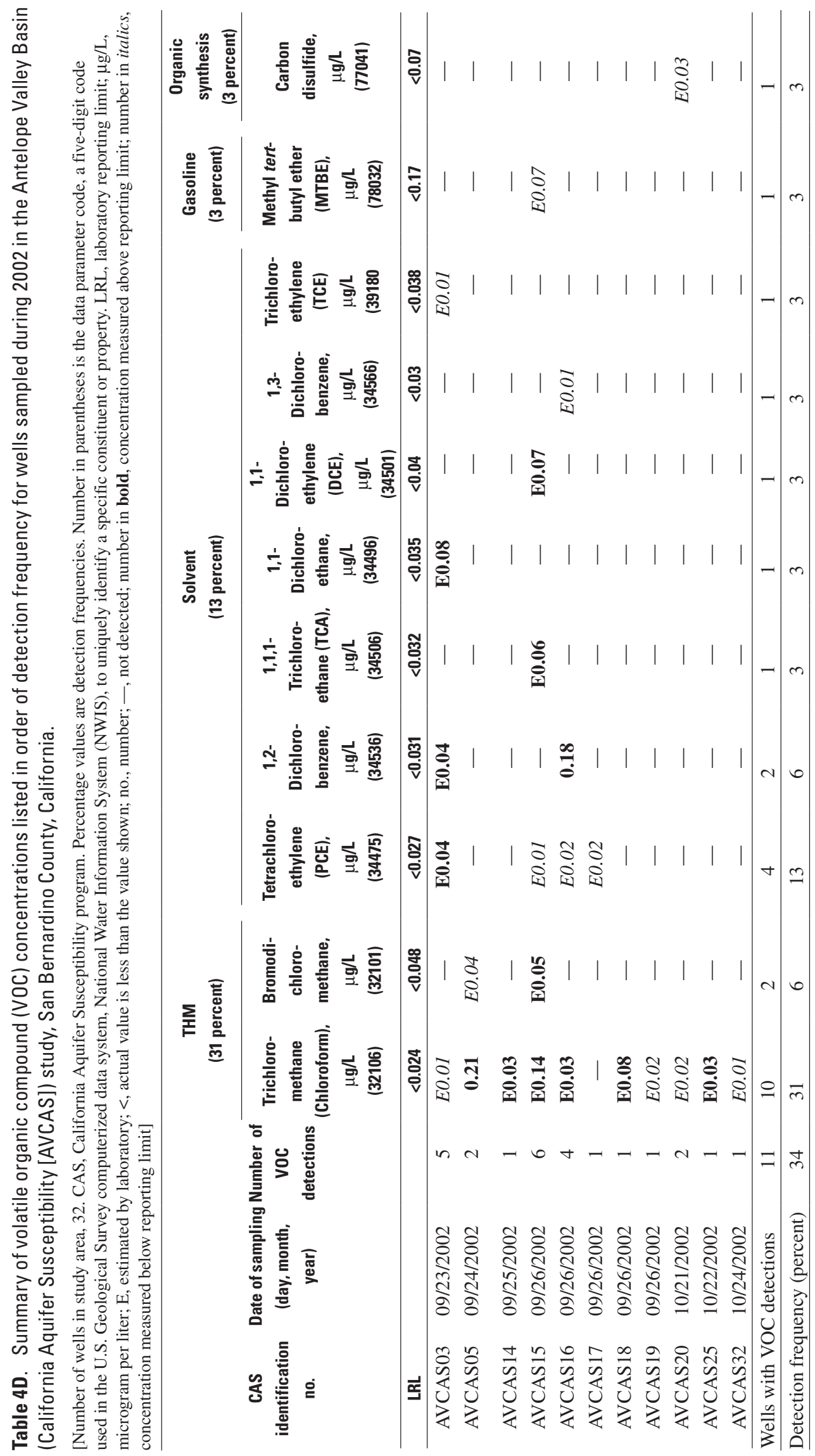




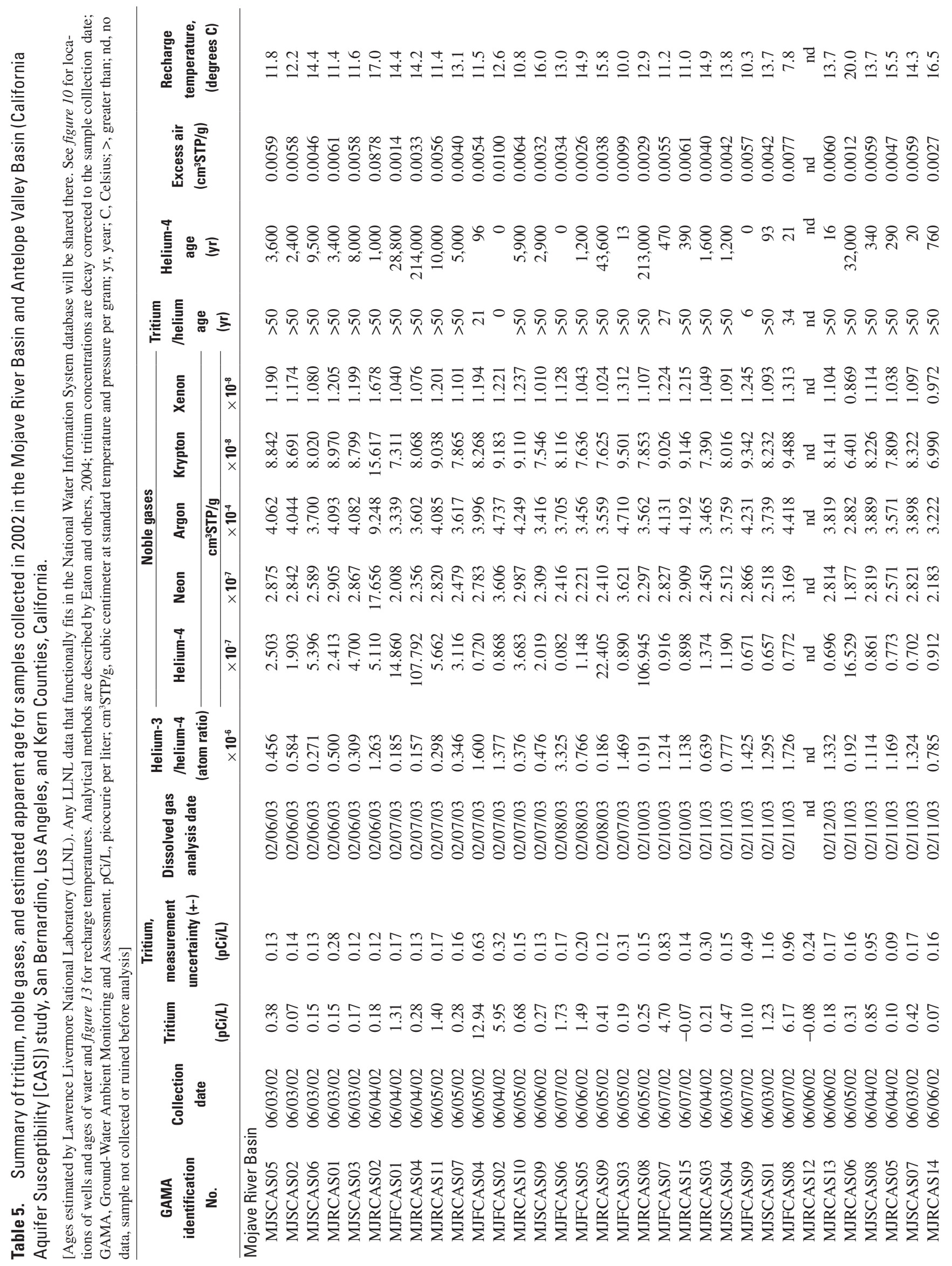




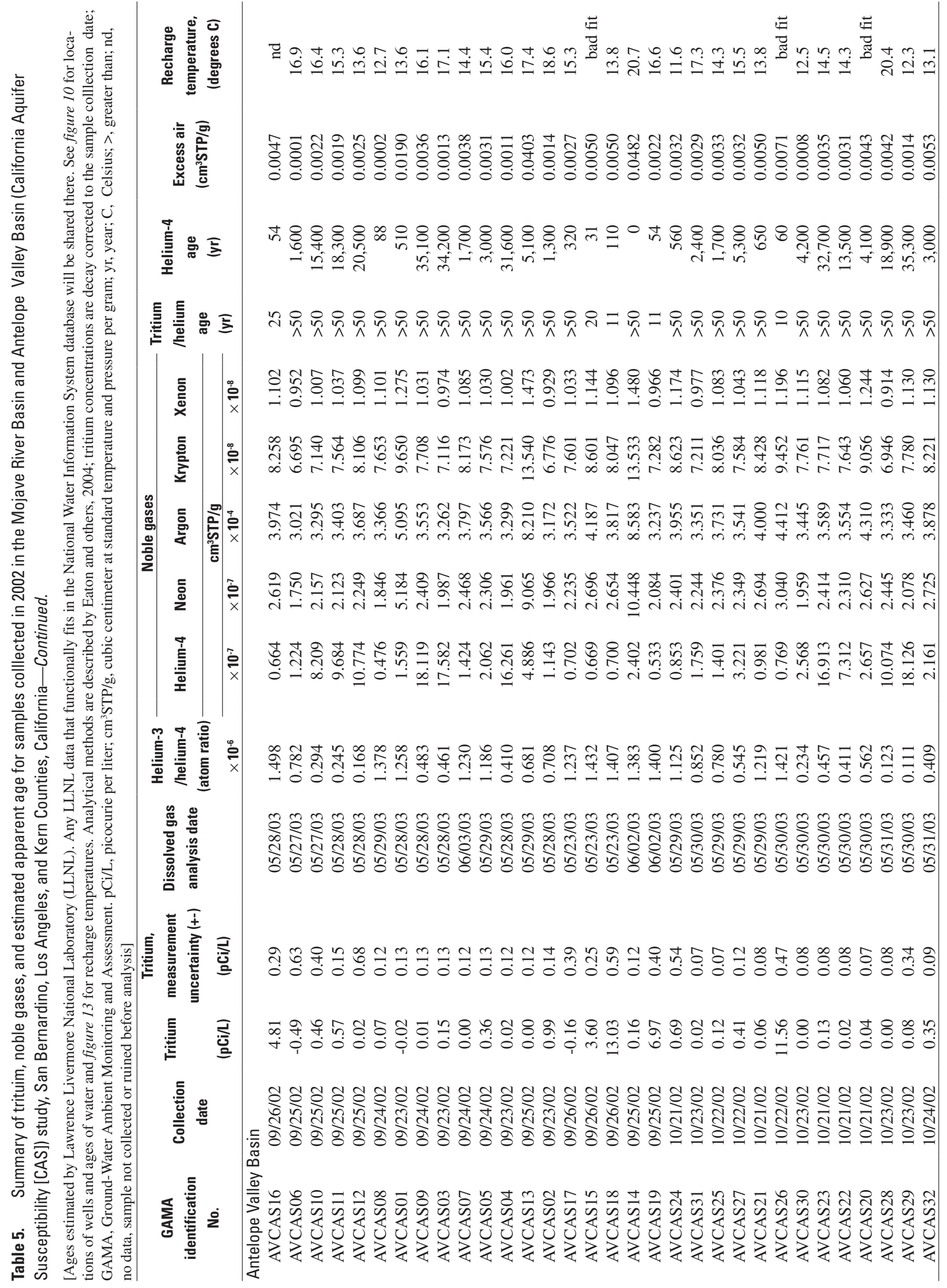



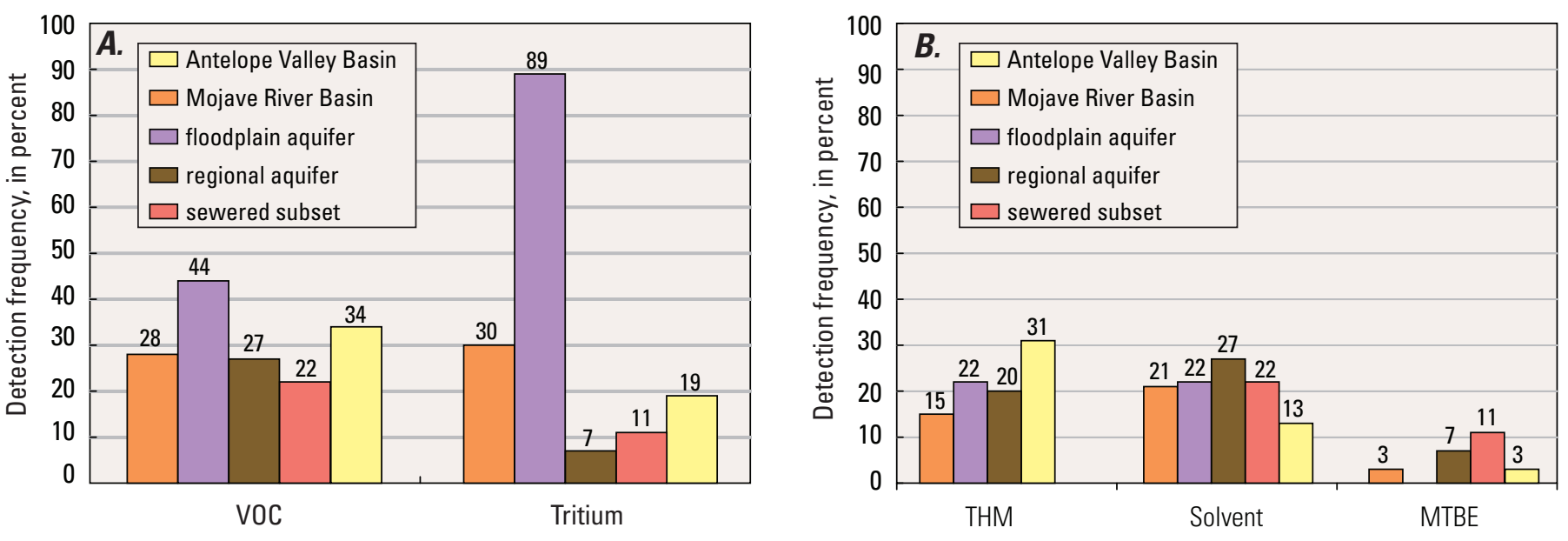

Figure 3. Detection frequency of $(A)$ volatile organic compounds (VOC) and tritium and $(B)$ specific classes of VOCs for the samples from the Mojave River and Antelope Valley Basins, California. THM, trihalomethane; MTBE, methyl tert-butyl ether.

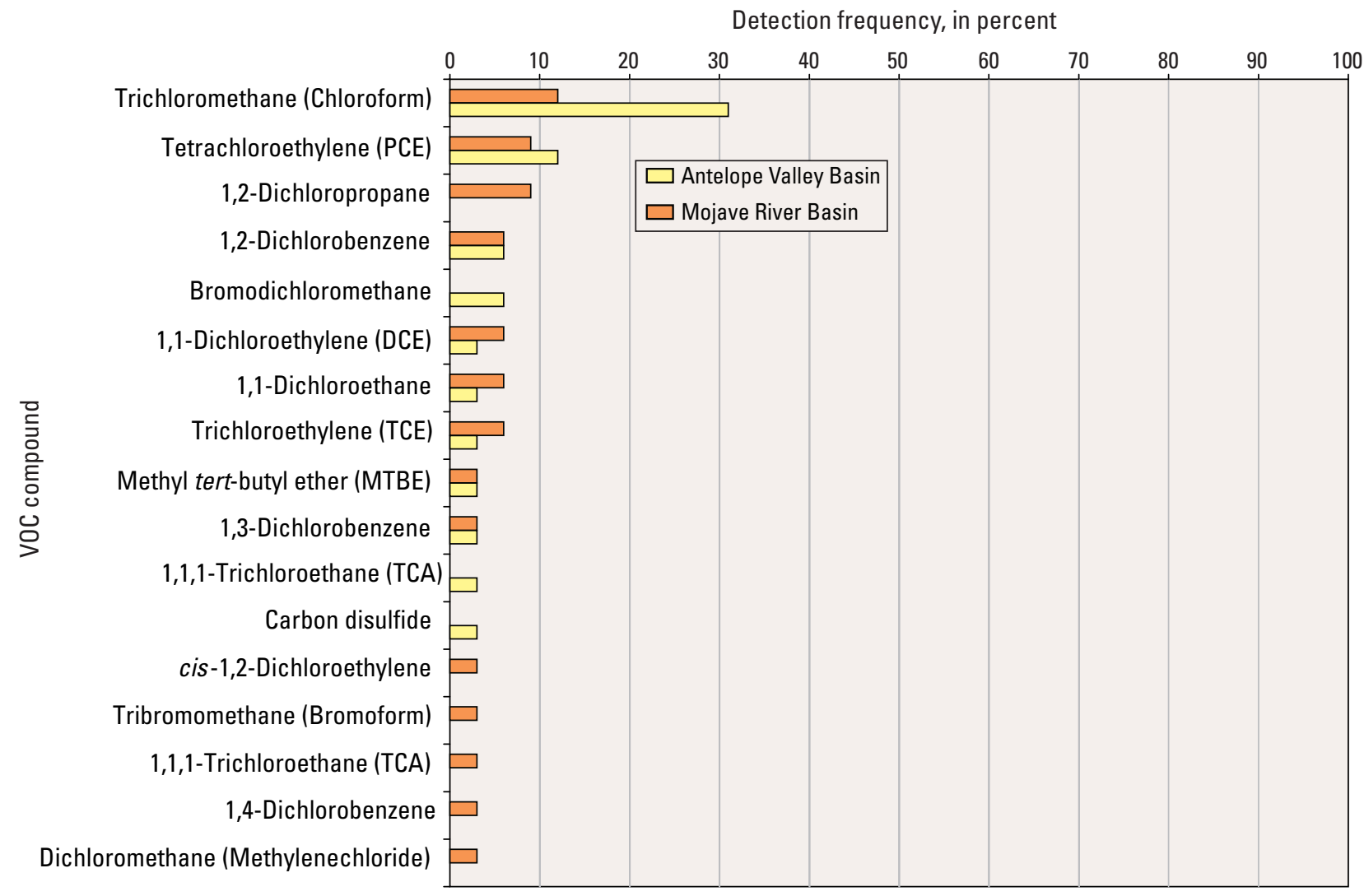

Figure 4. Detection frequencies of volatile organic compounds (VOC), in order of detection frequency, for samples from the Mojave River and Antelope Valley Basins, California. 

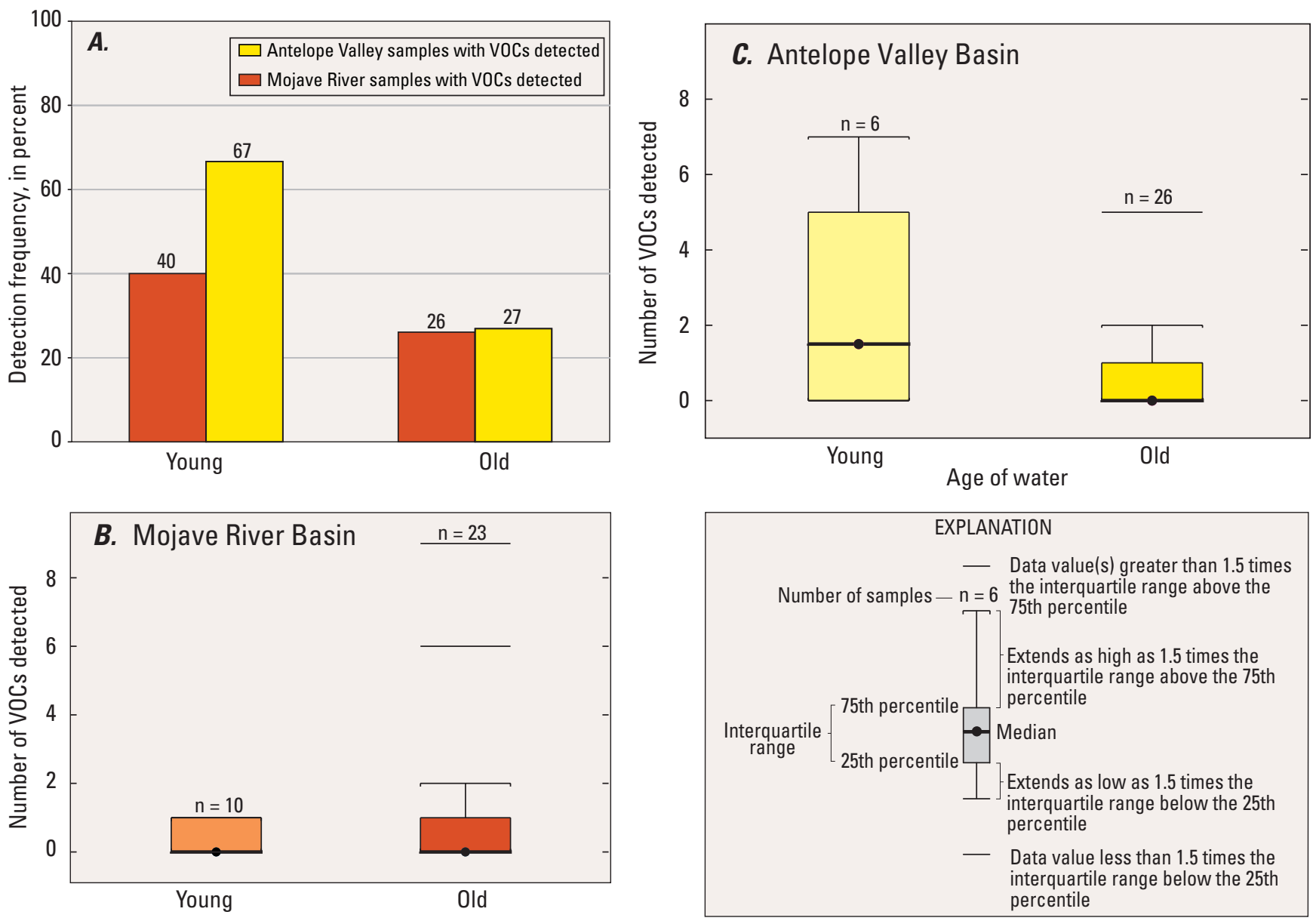

Figure 5. (A) Detection frequency of volatile organic compounds (VOC) in the Mojave River and the Antelope Valley samples by relative age, and the number of VOCs detected by ground-water age for samples from $(B)$ the Mojave River Basin and $(C)$ the Antelope Valley Basin, California.

\section{Evaluation of Aquifer Type, Well Depth, and Land Use as Explanatory Factors}

Aquifer type, depth of top of perforation, and land use within 1,640 ft of the well head were evaluated as possible explanatory factors for the variation of VOC detections in the Mojave River and the Antelope Valley Basins. The number of VOCs detected was used to evaluate the distribution of the VOCs based on the two aquifer types and one subset in the Mojave River Basin and on two aquifer types in the Antelope Valley Basin. The top of the uppermost perforations was used for the evaluation of depth because it represents the open interval closest to land surface. VOC detections also were evaluated by land use within 1,640 ft of the well head for both basins.

\section{Aquifer Type}

In the Mojave River Basin (fig. 6A), VOCs were detected more frequently in the floodplain aquifer ( 44 percent) than in the regional aquifer (27 percent) or the sewered subset of the regional aquifer (22 percent). Although VOCs were detected more frequently in the floodplain aquifer than in the regional and the sewered aquifer, there was no statistically significant difference ( $\mathrm{p}$-value $=0.7527$, Kruskal-Wallis Rank) between aquifer types. Further statistical tests also showed there was no statistically significant difference in VOC detections between the floodplain and the regional aquifer ( $\mathrm{p}$-value $=0.6942$, Wilcoxon Rank), the floodplain and the sewered subset of the regional aquifer ( $\mathrm{p}$-value $=0.4878$, Wilcoxon Rank), or the regional and the sewered subset of the regional aquifer 

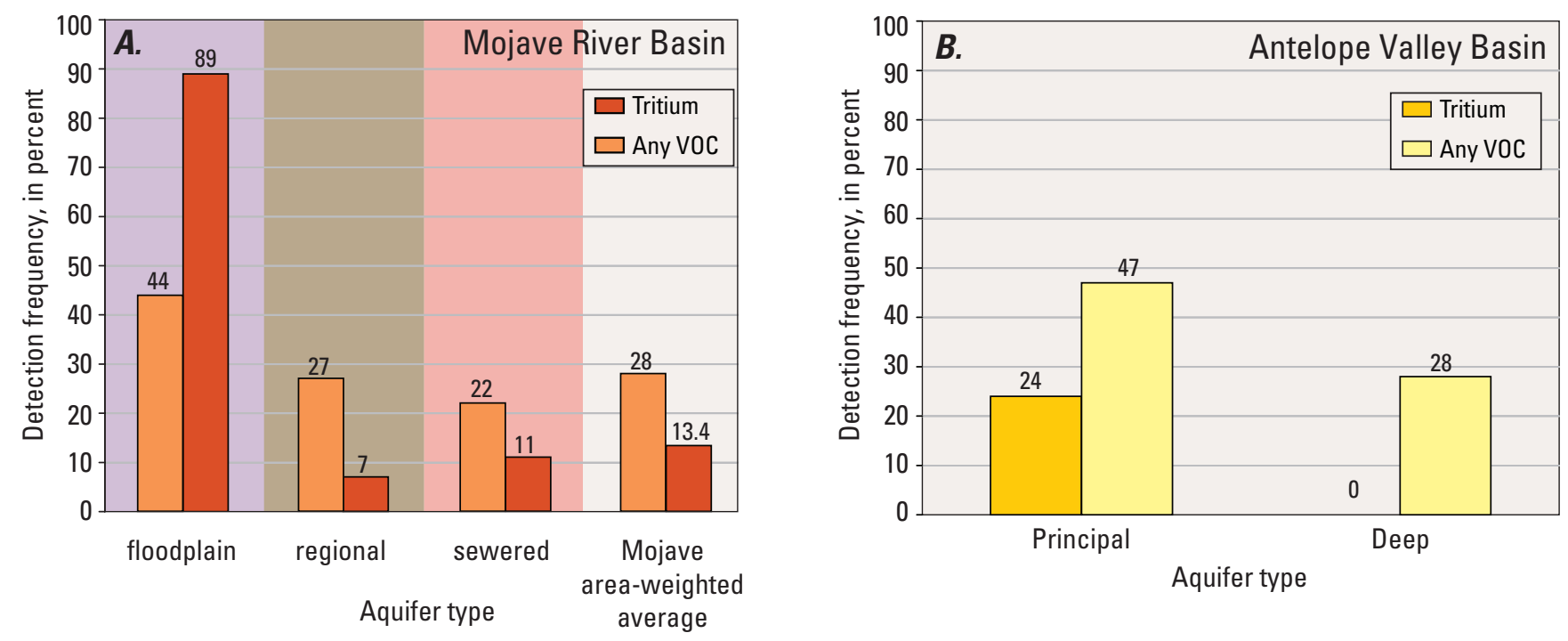

Figure 6. Volatile organic compounds (VOC) and tritium detection frequencies by aquifer type for $(A)$ the Mojave River Basin and (B) the Antelope Valley Basin, California.

(p-value $=0.7241$, Wilcoxon Rank). VOCs were detected in 28 percent of an area-weighted average of all Mojave River Basin samples. Tritium was detected more frequently in the floodplain aquifer ( 89 percent) than in the regional aquifer (7 percent) and the sewered subset of the regional aquifer (11 percent). A statistically significant correlation was found between the floodplain aquifer and the regional aquifer and the sewered subset of the regional aquifer ( $p$-value $=0.0006$; Kruskal-Wallis Rank). Tritium was detected in 13.4 percent of all the Mojave River Basin samples. The statistical tests of the VOC detections showed that aquifer type or subset was not an explanatory factor in the detection of VOCs in the Mojave River Basin but that aquifer type or subset was an explanatory factor for the presence of tritium.

In the Antelope Valley Basin (fig. 6B), VOCs were detected more frequently in the principal aquifer (47 percent) than in the deep aquifer (28 percent). Although VOCs were detected more frequently in the principal aquifer than in the deep aquifer, the number of VOCs detected was not statistically significantly different ( $p$-value $=0.2407$, Wilcoxon rank sum). Tritium also was detected more frequently in the principal aquifer ( 24 percent) than in the deep aquifer $(0$ percent). The statistical tests of VOC detections showed that aquifer type was not an explanatory factor for the detection of VOCs nor for the presence of tritium in the Antelope Valley Basin. Although not statistically significant, these results may reflect that an insufficient number of samples may have been collected.

\section{Depth to Top Perforation}

Detection frequencies were plotted by depth to the top perforation for the Mojave River and the Antelope Valley Basins (fig. 7A, B) to determine if depth to the top perforation was an explanatory variable for VOC detection. In the Mojave River Basin (fig. 7A), VOCs were detected more frequently in shallow wells ( 38 percent) than in the deep wells (15 percent). This difference was not statistically significant (p-value $=0.3097$, Wilcoxon rank sum). Tritium also was detected more frequently in shallow wells ( 63 percent) than in the deep wells ( 0 percent) in the Mojave River Basin. This difference is statistically significant ( $p$-value $=0.0001$, Wilcoxon rank sum). Results of the statistical tests showed that depth to the top of the perforation was not an explanatory factor for the detection frequency of VOCs. The tests also show that depth to the top of the perforation was an explanatory factor for the presence of tritium in the Mojave River Basin. This may be related to the fact that, in general, the top perforations in wells in the floodplain aquifer wells are shallower than those in the regional aquifer, and that there is no tritium in the regional aquifer. 

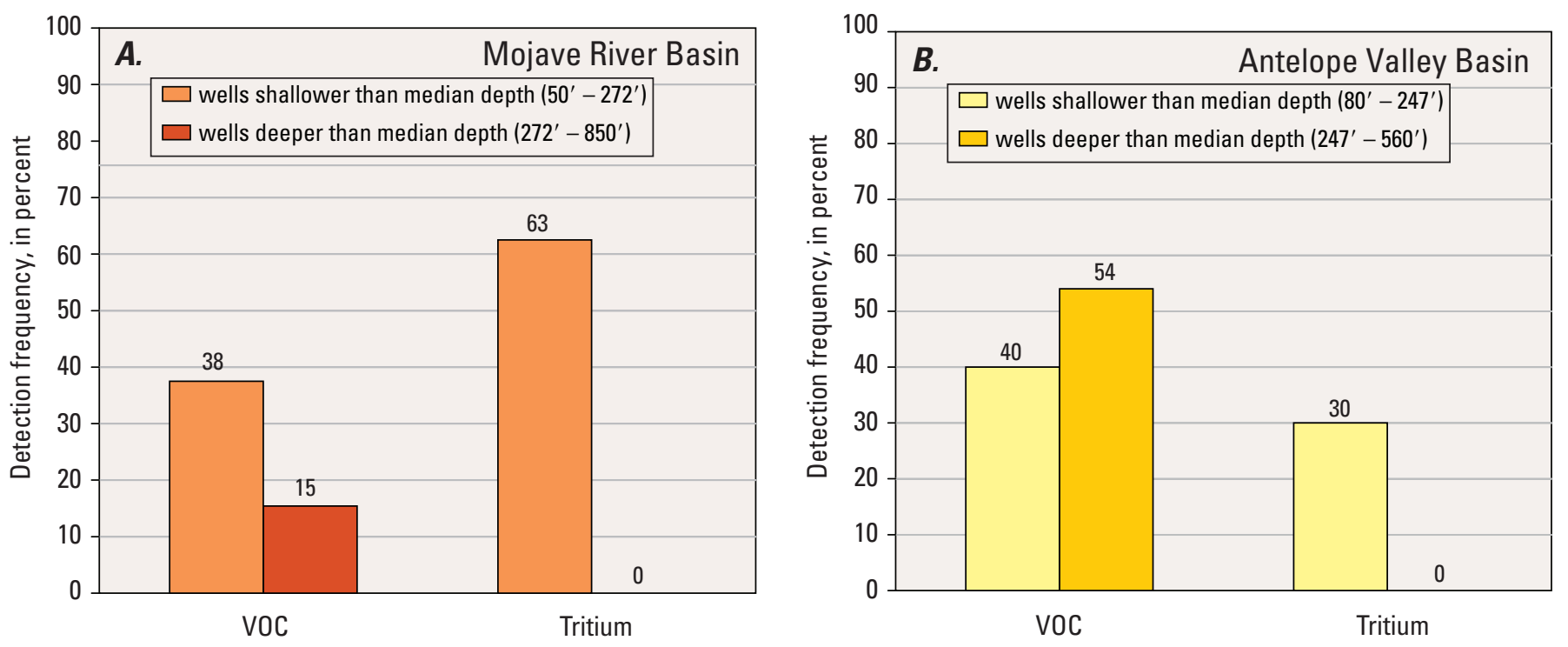

Figure 7. Volatile organic compounds (VOC) and tritium detection frequencies by depth for $(A)$ the Mojave River Basin and $(B)$ the Antelope Valley Basin, California.

In the Antelope Valley Basin (fig. 7B), VOCs were detected less frequently in shallow wells ( 40 percent) than in deep wells (54 percent). This difference is not statistically significant ( $\mathrm{p}$-value $=0.9085$; Wilcoxon rank sum). Tritium was detected more frequently in the shallow wells (30 percent) than in the deep wells ( 0 percent); this difference, however, is not statistically significant ( $\mathrm{p}$-value $=0.5573$, Wilcoxon rank sum). Although detection frequencies were greater for VOCs in the deep wells and for tritium in the shallow wells, results of statistical tests showed that depth to the top of the perforation was not an explanatory factor for the detection frequency of VOCs or for the presence of tritium in the Antelope Valley Basin. This may be related to the fact that grouping the wells by depth allowed wells perforated in the same aquifer to be in different depth categories Although tritium was detected more frequently in shallow wells, it was not detected in samples from most of the shallow and deep wells.

\section{Land Use}

Detection frequencies were plotted (showing the percentage of samples that had one or more VOC detections by land use within 1,640 ft of the well head in the Mojave River and Antelope Valley Basins) (fig. $8 A, B$ ) to determine if land use within $1,640 \mathrm{ft}$ of the well head was an explanatory variable for VOC detection. In the Mojave River Basin (fig. 8A), VOCs were detected slightly less frequently in low urban areas (less than the median urban land use) (29 percent) than in the high urban areas (greater than median urban land use) (31 percent). This difference is not statistically significant (p-value $=0.8938$, Wilcoxon rank sum). Tritium was detected more frequently in the low urban areas (44 percent) than in high urban areas (18 percent) in the Mojave River Basin. This may be because most of the floodplain wells that contained tritium were in low urban (residential and commercial) areas. Although tritium was detected more frequently in the low urban areas than in the high urban areas, there was no statistically significant difference in the detection between the low and the high urban areas ( $\mathrm{p}$-value $=0.0806$; Wilcoxon rank sum). This may be a result of insufficient samples collected for this study. Results of statistical tests showed that land use within 1,640 ft of the well head was not an explanatory factor for the VOC detection frequency or the presence of tritium in the Mojave River Basin.

In the Antelope Valley Basin (fig. 8B), VOCs were detected less frequently in low urban areas (35 percent) than in high urban areas (60 percent); however, this difference is not statistically significant ( $\mathrm{p}$-value $=0.1666$, Wilcoxon rank sum). Tritium was detected slightly less frequently in low urban areas (18 percent) than in high urban areas (20 percent). The difference is not statistically significant ( $p$-value $=0.1408$; Wilcoxon rank sum). Results of statistical analysis showed that land use within $1,640 \mathrm{ft}$ of the well head was not an explanatory factor for the VOC detection frequency or the presence of tritium in the Antelope Valley Basin. 

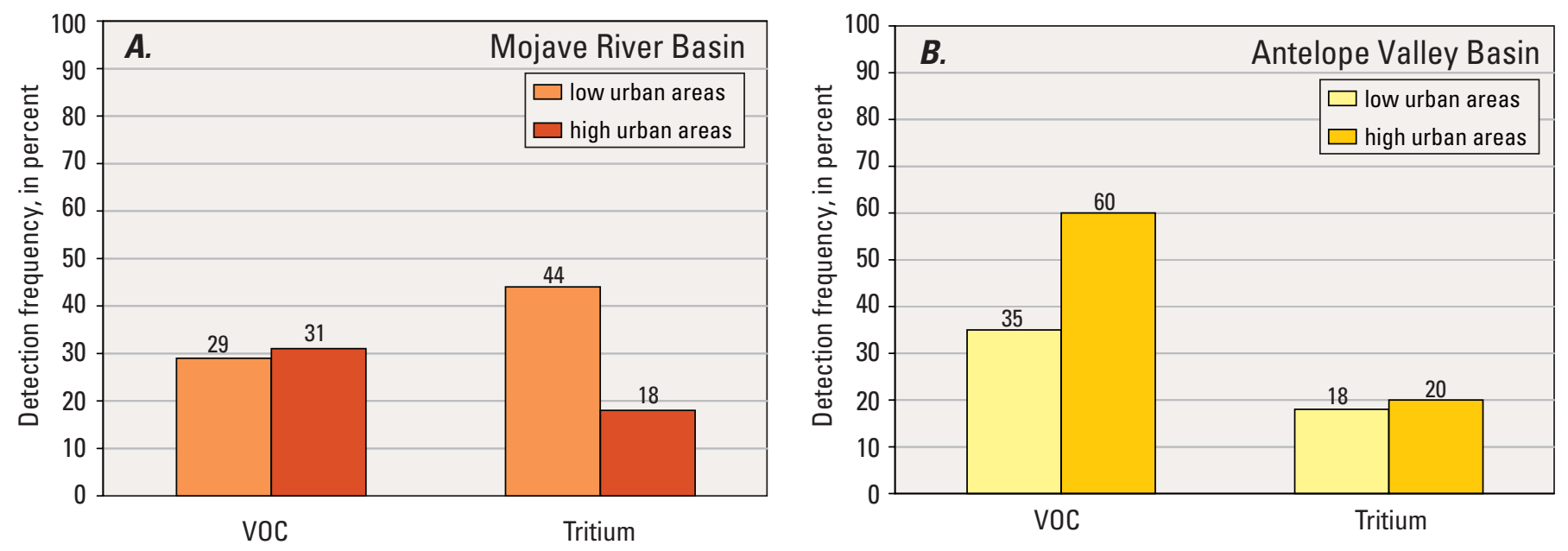

Figure 8. Volatile organic compounds (VOC) and tritium detection frequencies by degree of urbanization for $(A)$ the Mojave River Basin and $(B)$ the Antelope Valley Basin, California.

\section{Number of VOCs Detected and Tritium in the Mojave River and Antelope Valley Basins}

The areal distribution of wells sampled for this study, the number of VOCs detected, the relative age (young or old), the tritium $/{ }^{3} \mathrm{He}$ age (in yr), and the ${ }^{4} \mathrm{He}$ age (in yr) of water are shown in figures 9 and 10 . Samples having two or more VOC detections were coded as red; samples having one VOC detection were coded as yellow; and samples having no VOC detections were coded as blue. In addition, samples that have tritium present (young water) are surrounded by a white halo; samples that have no measurable tritium (old water) are surrounded by a black halo.

In the Mojave River Basin, two or more VOCs were detected in four of the samples and one VOC was detected in six of the samples (fig. 9A). The remaining 23 samples had no VOCs. Of the 33 samples collected, 10 contained young water (recharged after 1952), 9 of which were from wells located along the river in the floodplain aquifer (includes two northernmost wellls on figure 9A). Only one VOC was detected in four of the nine samples (44 percent) from the floodplain aquifer. One sample that contained young water was from the sewered area; no VOC was detected in that sample. Twenty-three of the 33 samples contained old water; one or more VOCs were detected in six (26 percent) of these samples. Four of the old water samples, shown by black halo, (17 percent) were from the regional aquifer, and two of the old water samples ( 9 percent) were from the sewered subset of the regional aquifer. VOCs can occur anywhere but were found slightly more frequently in the young water from the floodplain aquifer. Although VOCs were detected more frequently in the floodplain aquifer than in the regional aquifer and the sewered subset, generally only one VOC was detected in a sample. Conversely, samples from wells in the regional aquifer generally contained more than one VOC compound. Overall these data show that there was no apparent pattern for the spatial distribution of VOCs in the Mojave River Basin.

On the basis of the area-weighted average for VOC detections, the distribution of VOCs in the Mojave River Basin was not limited to a specific aquifer. The VOC detections generally seem to be distributed in areas of urban (residential and commercial) land use. With the exception of the one sample from the sewered area, young water was detected only in the floodplain aquifer, indicating recent recharge to this aquifer. Thus, tritium was not an indicator of aquifer susceptibility to contaminants in this desert basin.

Tritium $/{ }^{3} \mathrm{He}$ ground-water ages (time since recharge) were calculated from tritium and noble gas data collected during this study. These ages ranged from $0 \mathrm{yr}$ to greater than $50 \mathrm{yr}$ in the Mojave River Basin (fig. 10A). Tritium $/{ }^{3} \mathrm{He}$ ages ranged from 0 to $34 \mathrm{yr}$ in 5 wells in the floodplain aquifer. Ground-water ages were greater than $50 \mathrm{yr}$ in the remaining 4 wells in the floodplain aquifer. Tritium $/{ }^{3} \mathrm{He}$ ages were also greater than $50 \mathrm{yr}$ in all of the regional and sewered wells.

Ground-water ages were also estimated from observed radiogenic ${ }^{4} \mathrm{He}$ concentrations assuming a single value for the accumulation rate of $5 \times 10^{-11} \mathrm{~cm}^{3} \mathrm{STP} / \mathrm{g} / \mathrm{yr}$. This rate corresponds to the geometric mean of ${ }^{4} \mathrm{He}$ accumulation rates estimated by Kulongoski and others (2003) for this area. With the exception of two samples, these calculated ages ranged from 0 to about 40,000 yr in the Mojave River Basin (fig. 10B). The ${ }^{4} \mathrm{He}$ ages ranged from 0 to about $100 \mathrm{yr}$ in six wells in the floodplain aquifer, indicating recent ground-water recharge. Helium-4 ages were slightly older (about 470 and about $1,200 \mathrm{yr}$ ) in two wells in the floodplain aquifer. Helium- 4 ages ranged from about $20 \mathrm{yr}$ near the mountain front to about $40,000 \mathrm{yr}$ in the regional and sewered wells. Relatively young ground-water ages (20 and about $90 \mathrm{yr}$ ) also were estimated in two wells in the sewered subset of the regional aquifer, suggesting that recent recharge has occurred in this area. 


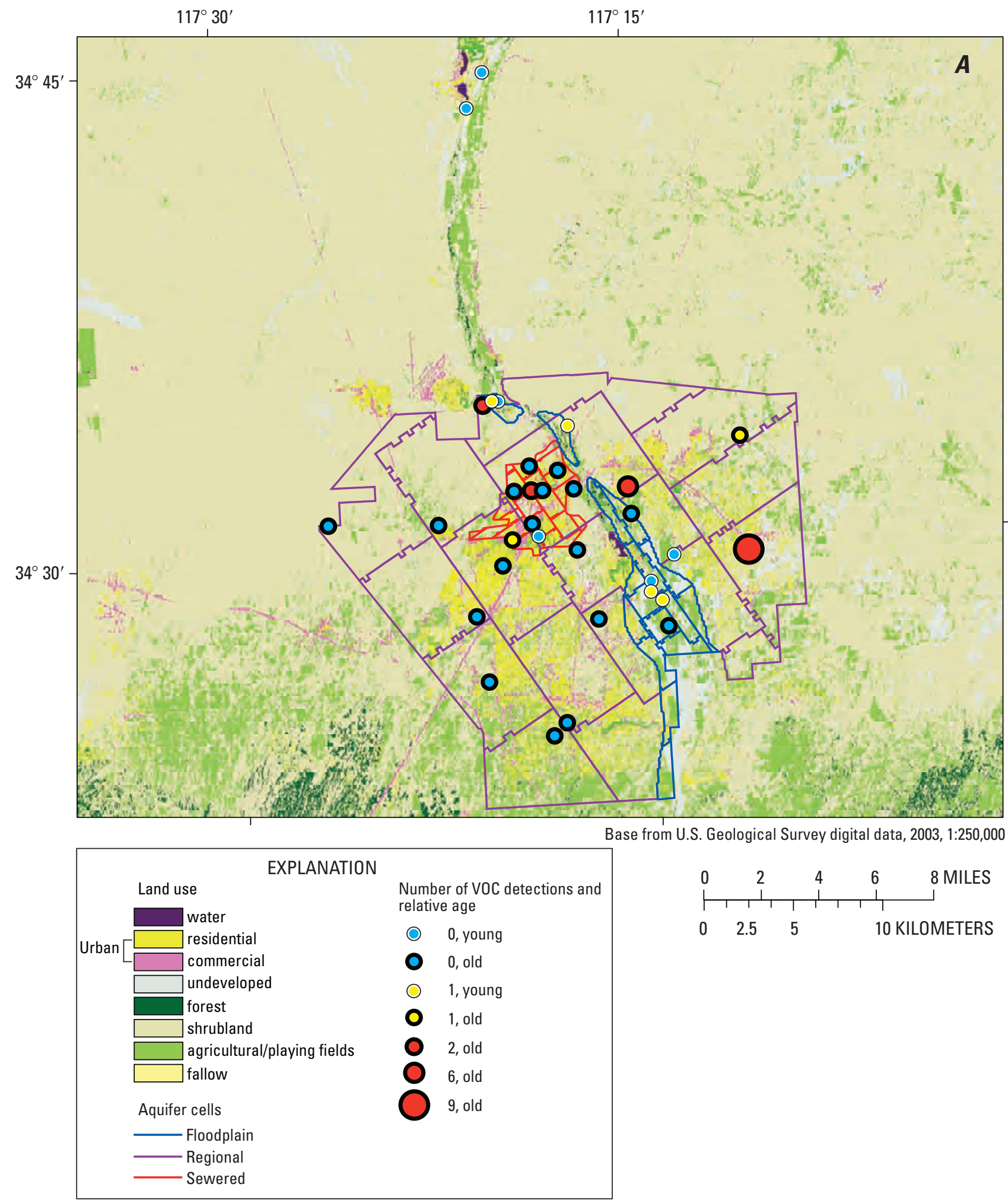

Figure 9. Location of sampling sites, volatile organic compound (VOC) detections, and relative age of water in the (A) Mojave River and (B) Antelope Valley Basins, San Bernardino, Los Angeles, and Kern Counties, California. >, greater than. 


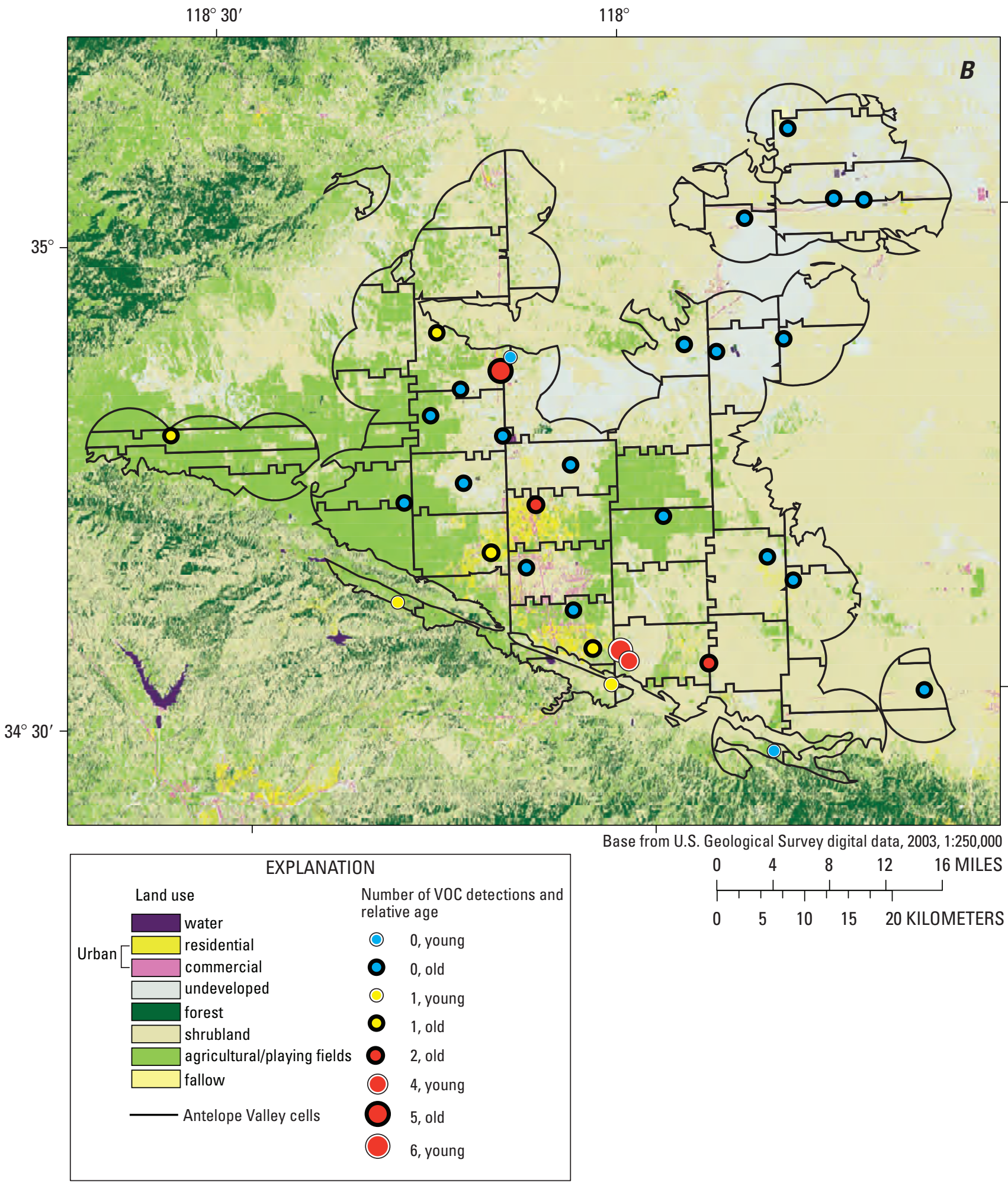

Figure 9. Continued. 


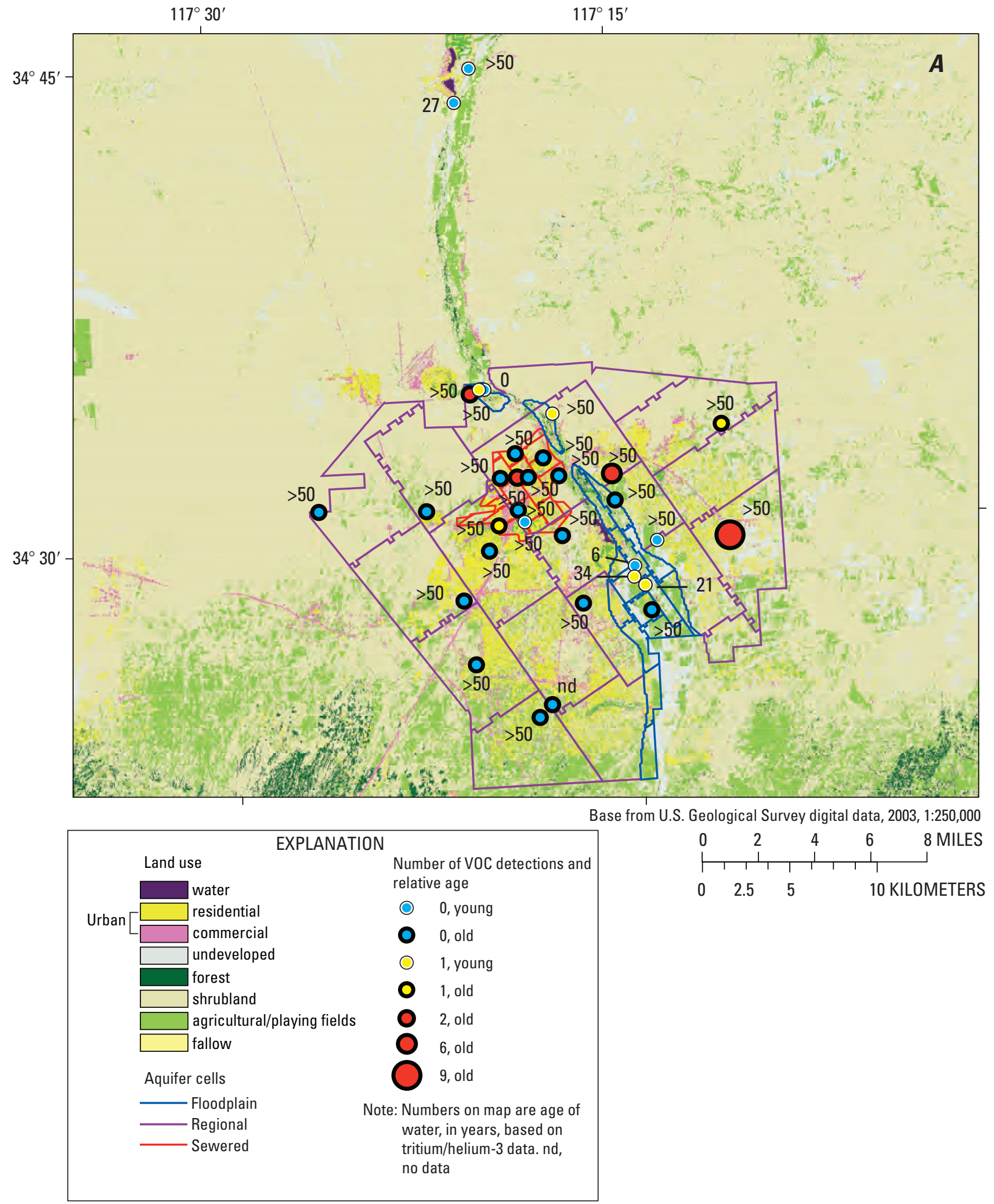

Figure 10. Location of sampling sites, volatile organic compound (VOC) detections, and age of water in the (A \& B) Mojave River and (C \& D) Antelope Valley Basins, San Bernardino, Los Angeles, and Kern Counties, California. 


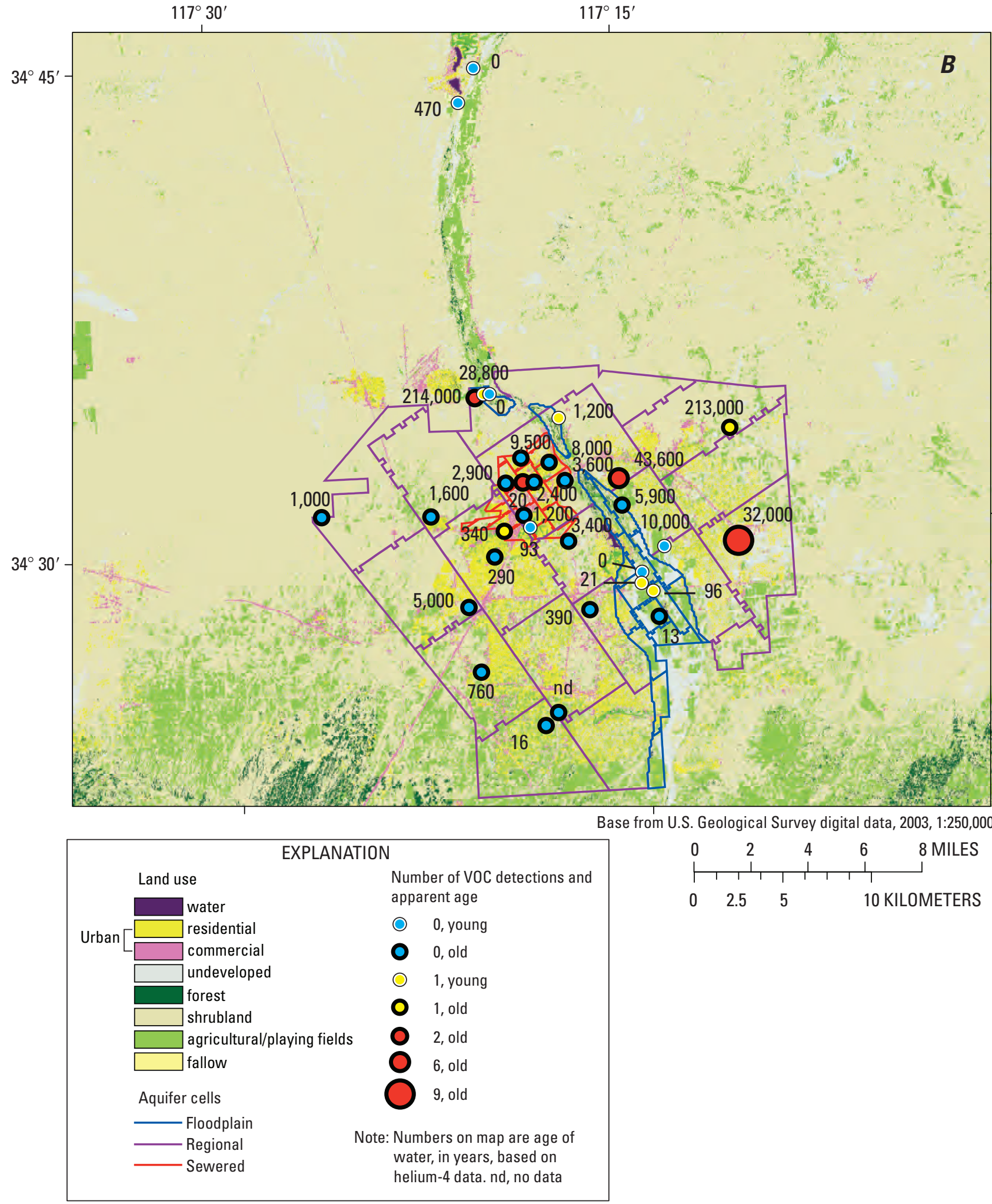

Figure 10. Continued. 


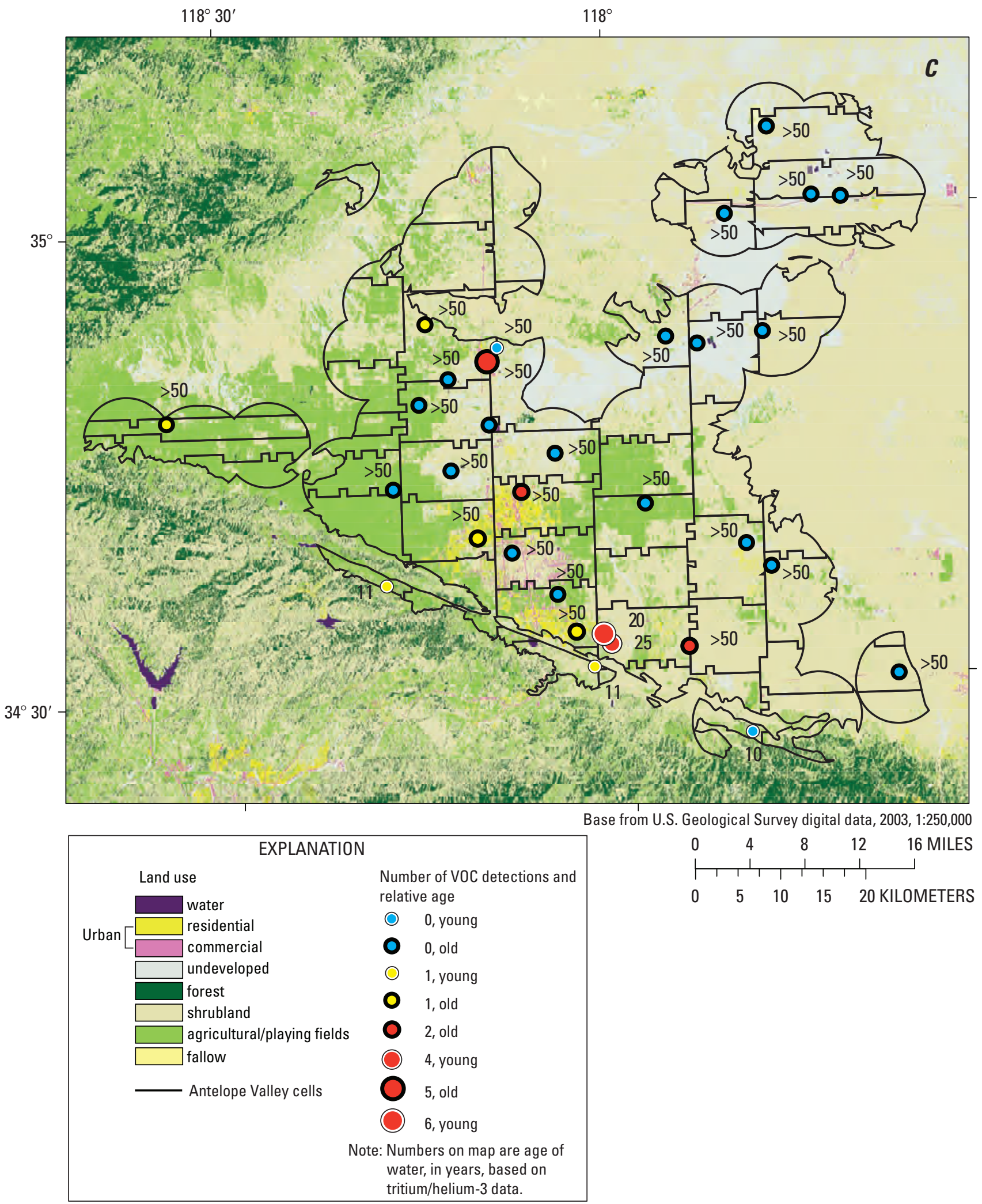

Figure 10. Continued. 


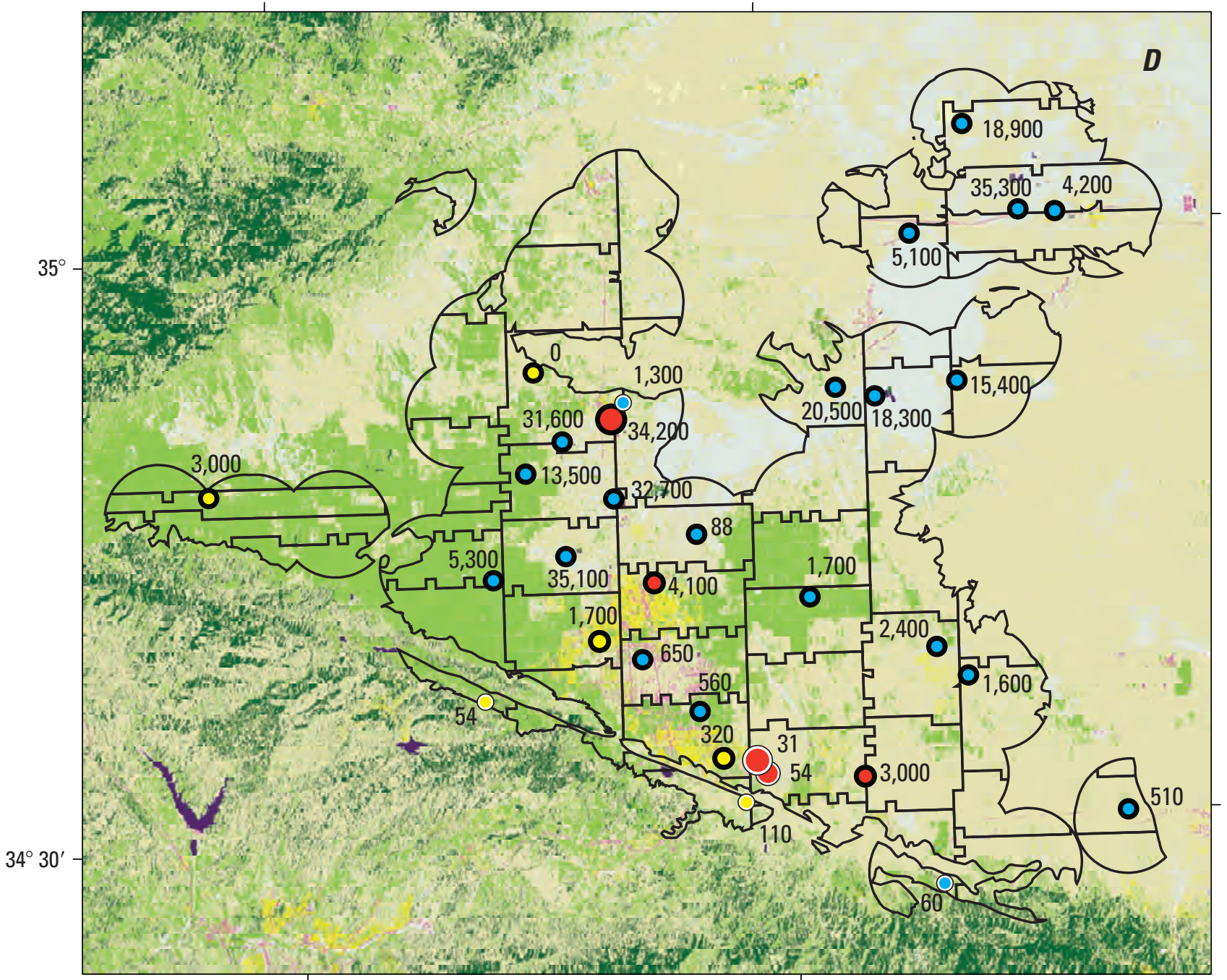

Base from U.S. Geological Survey digital data, 2003, 1:250,000

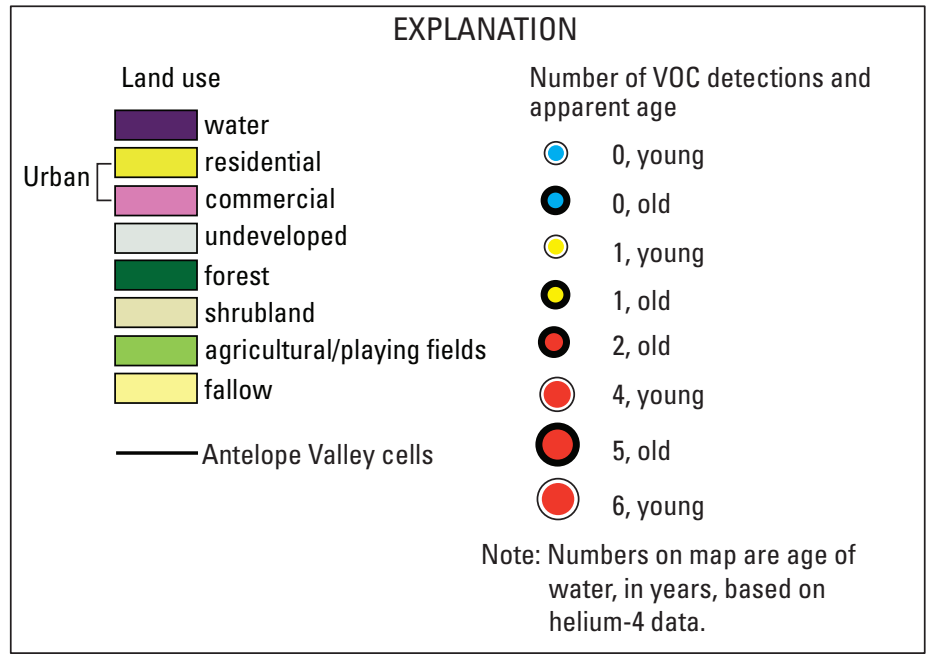

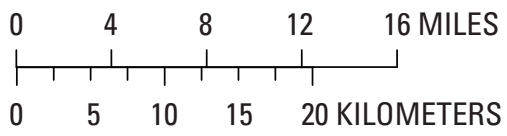

Figure 10. Continued. 
With the exception of the two apparent ages in excess of $200,000 \mathrm{yr}$, the tritium $/{ }^{3} \mathrm{He}$ and ${ }^{4} \mathrm{He}$ ages estimated for this study are in the range of the ${ }^{14} \mathrm{C}$ ages reported by Izbicki and Michel (2004) and the ${ }^{4} \mathrm{He}$ ages calculated by Kulongoski and others (2003) for the western part of the Mojave Desert. Interpreted ${ }^{14} \mathrm{C}$ ages of ground water in the Mojave River Basin ranged from less than 10,000 yr in the floodplain aquifer to greater than 30,000 $\mathrm{yr}$ in the regional aquifer (Izbicki and Michel, 2004). Older apparent ground-water ages estimated in two wells in the regional aquifer (greater than 200,000 yr) may not be entirely unreasonable because the one located near the floodplain is downstream from a bedrock ridge that forces deep older ground water to the surface and the other may also tap deep older ground water. However, ground water more than 200,000 yr old, even in the regional aquifer, is an order of magnitude older than the ${ }^{14} \mathrm{C}$ estimated by other studies in this area and suggests an external helium source. Therefore, the apparent ages of ground water in this area could be adjusted by using a higher ${ }^{4} \mathrm{He}$ accumulation rate to provide a more reasonable apparent age.

In the Antelope Valley Basin, two or more VOCs were detected in five of the samples and one VOC was detected in six of the samples (fig. 9B). The remaining 21 samples had no VOCs. Of the 32 samples collected, six contained young water, five of which were from wells located at the base of the mountains. Two or more VOCs were detected in two of the six samples (33 percent), one VOC was detected in two samples (33 percent), and no VOCs were detected in two samples (33 percent). The remaining 26 samples contained old water. One or more VOCs were detected in 7 of the 26 samples of old water (27 percent). Three of the 7 samples had two or more VOCs; four samples had one VOC. The distribution of VOCs in the Antelope Valley samples seems to be concentrated in the urban areas or near the mountain front where most of the young water was detected.

Tritium $/{ }^{3} \mathrm{He}$ ground-water ages ranged from as young as $10 \mathrm{yr}$ to greater than $50 \mathrm{yr}$ in the Antelope Valley Basin (fig. 10C). Ground-water ages ranged from 10 to $25 \mathrm{yr}$ near the mountain front. Apparent ${ }^{4} \mathrm{He}$ ground-water ages, calculated from ${ }^{4} \mathrm{He}$ concentrations in ground-water samples and assuming a global accumulation rate of $5 \times 10^{-11} \mathrm{~cm}^{3} \mathrm{STP} /$ $\mathrm{g} / \mathrm{yr}$, ranged from 0 to about 35,000 $\mathrm{yr}$ in the Antelope Valley Basin (fig. 10D). The ground-water ages generally were young near the mountain front and increased in age farther north from the mountains. Ground-water ages also were slightly younger near some of the playas (dry lakes). An apparent age of 0 year near the playa in the Antelope Valley Basin is unrealistic and could be adjusted by using a different ${ }^{4} \mathrm{He}$ accumulation rate to provide a more reasonable age. The tritium $/{ }^{3} \mathrm{He}$ and ${ }^{4} \mathrm{He}$ ages estimated for the Antelope Valley Basin are in the range of ${ }^{14} \mathrm{C}$ ages reported by Izbicki and Michel (2004) for the western part of the Mojave Desert.

The difference in VOC detections and the spatial distribution of VOCs between the Mojave River and Antelope Valley
Basins also was evaluated. Figure 11 shows the depth to the top perforation and percentage urban land use within 1,640 ft of the well head for the Mojave River and Antelope Valley Basins. The difference between the depths to the top of the perforations in these two areas is not statistically significant ( $\mathrm{p}$-value $=0.7983$, Wilcoxon rank sum). However, the percentage of urban land use within 1,640 ft of the well head between the two areas was significantly different (p-value $=<0.0001$,
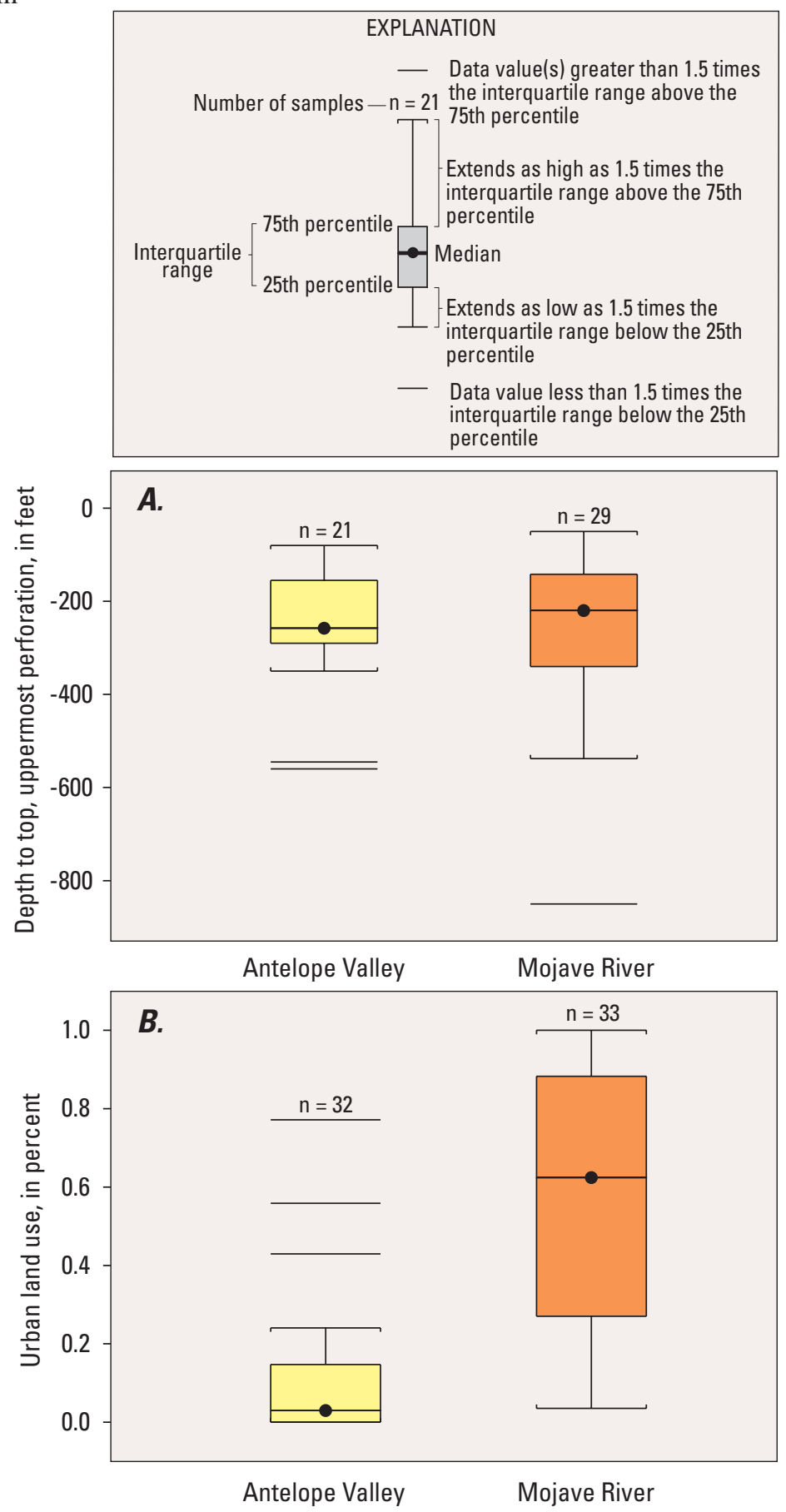

Figure 11. Variation of $(A)$ depths of top of perforations of wells and $(B)$ land use in the Mojave River and Antelope Valley Basins, California. 
Wilcoxon rank sum). Thus, the differences between VOC detection and distribution are probably related to differences in urban land use within $1,640 \mathrm{ft}$ of the well head in the two basins.

\section{Isotopic Composition of Mojave and Antelope Valley Samples}

The stable isotopes of oxygen-18 $\left(\delta^{18} \mathrm{O}\right)$ and deuterium $(\delta \mathrm{D})$ in the Mojave River and Antelope Valley Basins were analyzed. As an indicator of the source of ground-water recharge, the isotopic composition of these samples was evaluated relative to the global meteoric water line, a linear relation between $\delta^{18} \mathrm{O}$ and $\delta \mathrm{D}$ in meteoric waters throughout the world (Craig, 1961) (fig. 12). Because $\delta^{18} \mathrm{O}$ and $\delta \mathrm{D}$ values for water vapor become isotopically lighter (more negative) due to the isotopic fractionation during the transfer from the ocean surface to the vapor phase and to condensation (for example, as precipitation) as vapor moves inland, $\delta^{18} \mathrm{O}$ and $\delta \mathrm{D}$ can be used as an indicator of the source of the ground water. The isotopic composition of these samples also was evaluated relative to VOC detections to determine correlations.

Figure 12 shows $\delta^{18} \mathrm{O}$ and $\delta \mathrm{D}$ isotopic compositions for the Mojave River and the Antelope Valley Basins. All samples generally plot along the global meteoric water line (Craig, 1961). The isotopic composition of the Mojave River samples for the floodplain aquifer ranged from -7.9 to $-9.4 \%$ (per mil) for $\delta^{18} \mathrm{O}$ and from -58.3 to $-64.7 \%$ ofor $\delta \mathrm{D}$; for the regional aquifer, -8.5 to $-12.5 \%$ o for $\delta^{18} \mathrm{O}$ and from -55.3 to $-92.5 \%$ o for $\delta \mathrm{D}$; and for the sewered subset, -8.8 to $-9.9 \%$ o for $\delta^{18} \mathrm{O}$; and -60.1 to $-64.9 \%$ ofor $\delta \mathrm{D}$. The isotopic composition of the Antelope Valley samples ranged from -8.8 to $-13.2 \%$ o for $\delta^{18} \mathrm{O}$ and from -59.5 to $-103.5 \%$ for $\delta \mathrm{D}$. Also shown on figure 12 are samples that had VOC detections for the Mojave River and the Antelope Valley Basins.

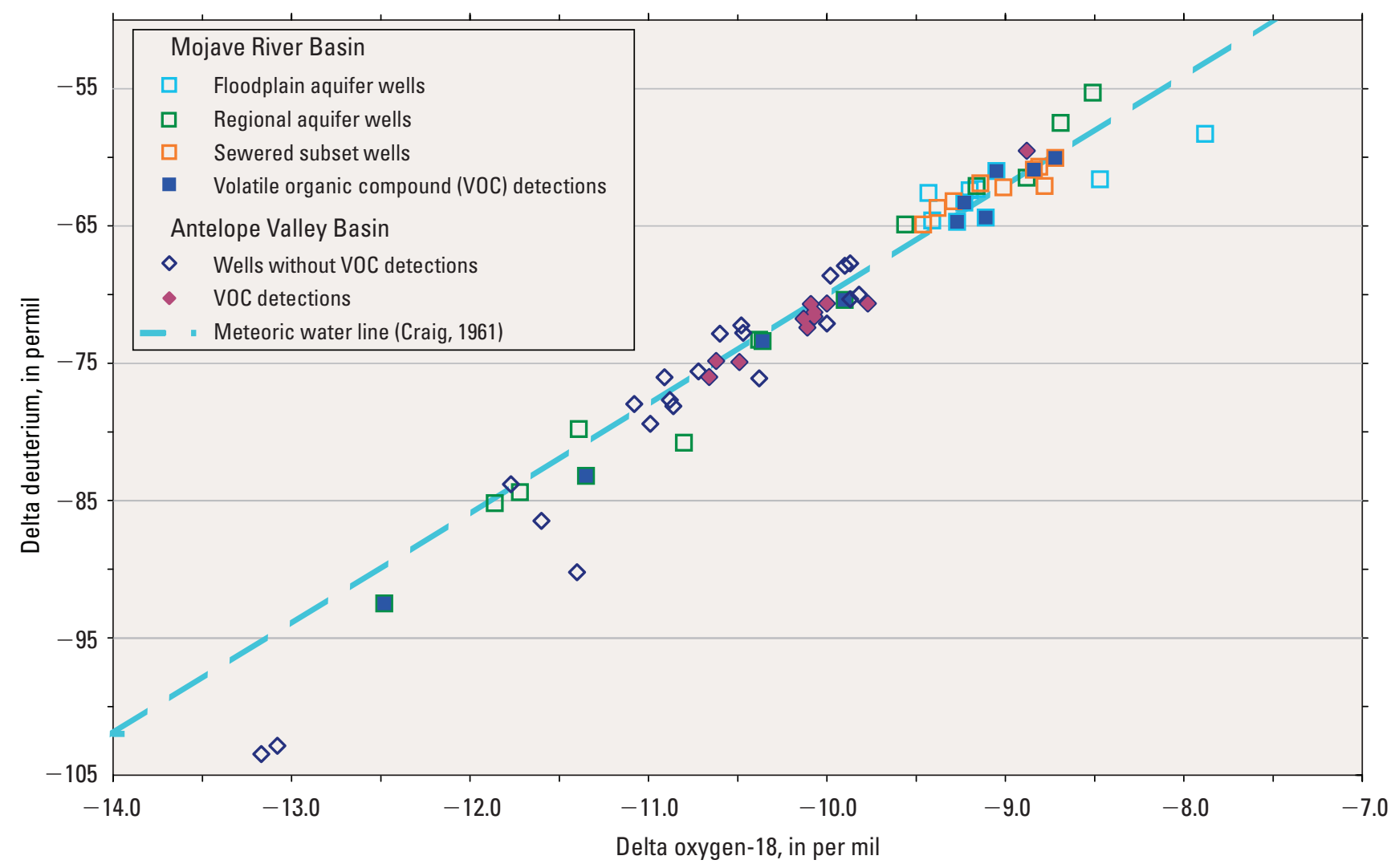

Figure 12. Isotopic composition of ground-water samples from the Mojave River and Antelope Valley Basins, San Bernardino, Los Angeles, and Kern Counties, California. 
In general, samples from the Mojave River floodplain aquifer and the sewered subset were isotopically heavier (less negative) than samples from most of the regional aquifer and from Antelope Valley (fig. 12). The samples from the regional aquifer were spread over almost the entire range of isotopic compositions. This indicates the recharge along the Mojave River and in the sewered area resulted from precipitation from different climatic conditions than recharge in most of the regional aquifer and the Antelope Valley. Six samples with VOC detections from the floodplain aquifer and all samples in the sewered subset appear to be tightly clustered (fig. 12). This is because the isotopic composition of the samples from the floodplain aquifer and the sewered subset cover a smaller range of values, indicating that these samples have similar source water. However, closer examination of the floodplain aquifer and sewered subset samples do not show any apparent trend (fig. 12). The four samples from the regional aquifer with VOC detections are scattered over the half of the range of the samples that are isotopically lighter but also do not appear to have any definite trend. There does not appear to be any distinct pattern between the samples from the Mojave River Basin that had VOC detections and the samples that had no VOC detections. Thus, the distribution of samples that contained one or more VOCs was not correlated to the source of water.

The 11 samples from the Antelope Valley Basin having VOC detections are scattered over the heavier range (less negative) of isotopic compositions for the Antelope Valley Basin samples (fig. 12). This may be related to the proximity of the well to mountain front recharge; however, closer examination showed that samples with VOCs were also detected miles away from mountain front recharge. Thus, the distribution of samples with one or more VOCs was not correlated to the source of water.

\section{Noble Gases and Recharge Temperature}

The concentrations of neon (Ne), argon (Ar), krypton $(\mathrm{Kr})$, and xenon $(\mathrm{Xe})$ were measured in the samples from the Mojave River and Antelope Valley Basins. Noble gases have been used as tracers to evaluate ground-water flow and recharge processes, paleothermometry, and to calculate the depth of ground-water circulation (Mazor, 1991; Manning and Solomon, 2003). Atmospheric noble gases equilibrate with recharging ground water based on its temperature, salinity, and the partial pressure of the noble gases in the atmosphere, a function of the recharge altitude (Mazor, 1991). Once the ground water reaches the saturated zone, equilibration ceases, and the noble gas concentrations in the recharging ground water are preserved as the water moves through the aquifer. The recharge temperature can therefore be calculated using the concentrations of the noble gases in a ground-water sample. The altitude of the well was adopted as the recharge altitude in this study because the altitude at which the water recharged is unknown; thus, this calculated recharge temperature represents a maximum recharge temperature. Excess air concentrations (dissolved atmospheric gases in excess of equilibrium values) were determined from dissolved noble gas concentrations.

Recharge temperatures of ground water in the Mojave River Basin ranged from $7.8^{\circ}$ to $20^{\circ} \mathrm{C}$ (fig. 13A). Recharge temperatures in ground water were generally lowest in the floodplain aquifer, ranging from $7.8^{\circ}$ to $14.9^{\circ} \mathrm{C}$. Recharge temperatures in ground water generally were $2^{\circ}$ to $4^{\circ} \mathrm{C}$ warmer in the sewered subset and $4^{\circ}$ to $5^{\circ} \mathrm{C}$ warmer in the regional aquifer than in the floodplain aquifer. Recharge temperatures in ground water ranged from $11.6^{\circ}$ to $16^{\circ} \mathrm{C}$ in the sewered subset and from $11^{\circ}$ to $20^{\circ} \mathrm{C}$ in the regional aquifer.

The lower recharge temperatures estimated for ground water in the floodplain aquifer suggest that cold river water lowers subsurface temperature causing recharge temperatures to be lower than the mean annual temperature of the region. Slightly warmer recharge temperatures in ground water in the sewered subset suggest mixing between cooler water from the floodplain aquifer and warmer water from the regional aquifer. The warmest recharge temperatures were present in ground water in the regional aquifer of the Mojave River Basin and in the Antelope Valley Basin. 


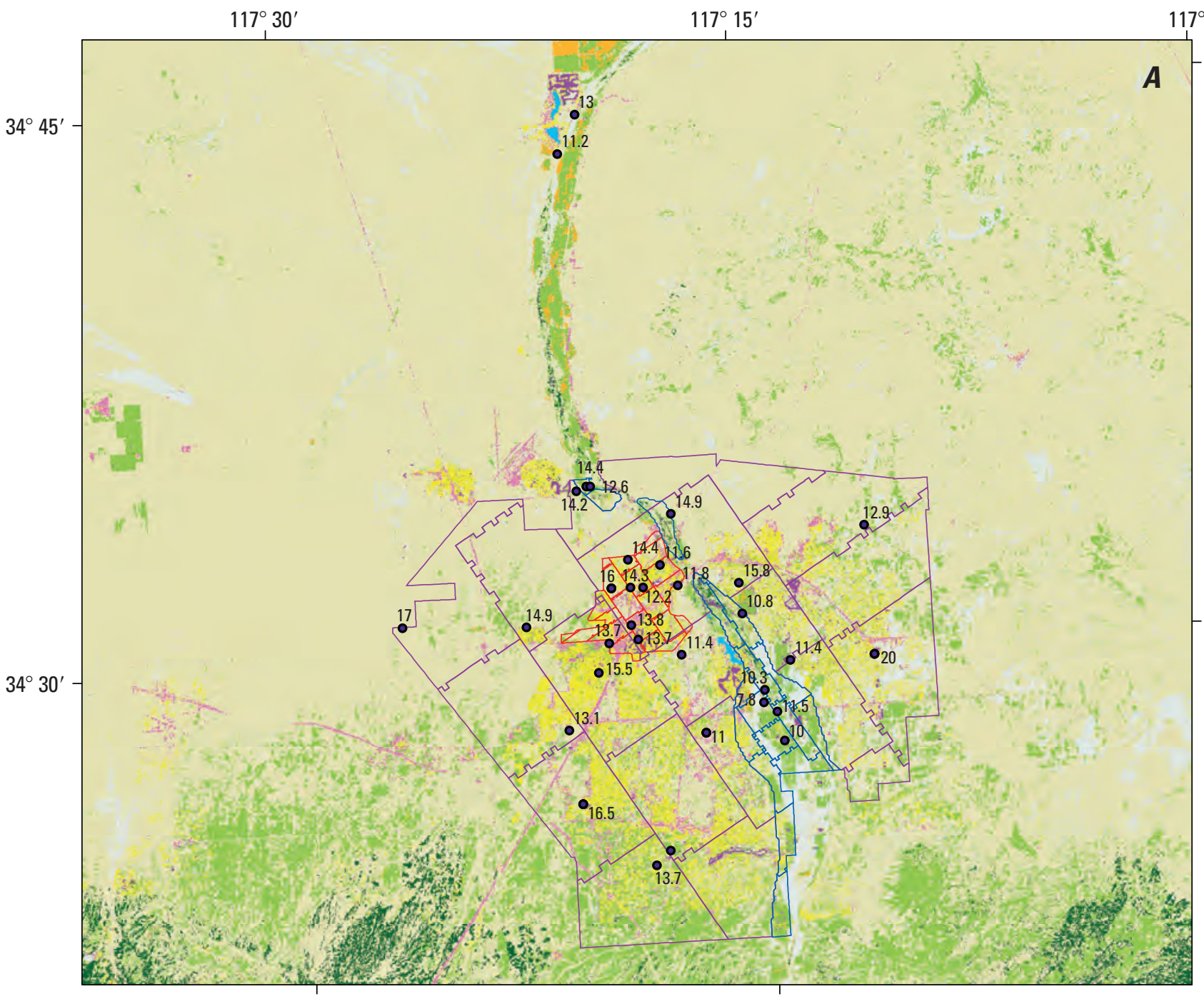

\begin{tabular}{|c|c|c|}
\hline & & EXPLANATION \\
\hline & Land u & \\
\hline & & water \\
\hline Urban & & residential \\
\hline & & commercial \\
\hline & & undeveloped \\
\hline & & forest \\
\hline & & shrubland \\
\hline & & agricultural/playing fields \\
\hline & & fallow \\
\hline & Aquife & er cells \\
\hline & & - Floodplain \\
\hline & & - Regional \\
\hline & - & - Sewered \\
\hline & •10 & $\begin{array}{l}\text { Location of well and estimated recharge } \\
\text { temperature, in degrees Celsius }\end{array}$ \\
\hline
\end{tabular}

Base from U.S. Geological Survey digital data, 2003, 1:250,000

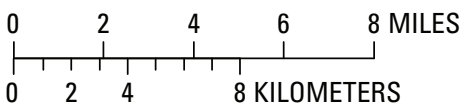

Figure 13. Location of sampling sites and estimated recharge temperature of water in the (A) Mojave River and (B) Antelope Valley Basins, San Bernardino, Los Angeles, and Kern Counties, California. 


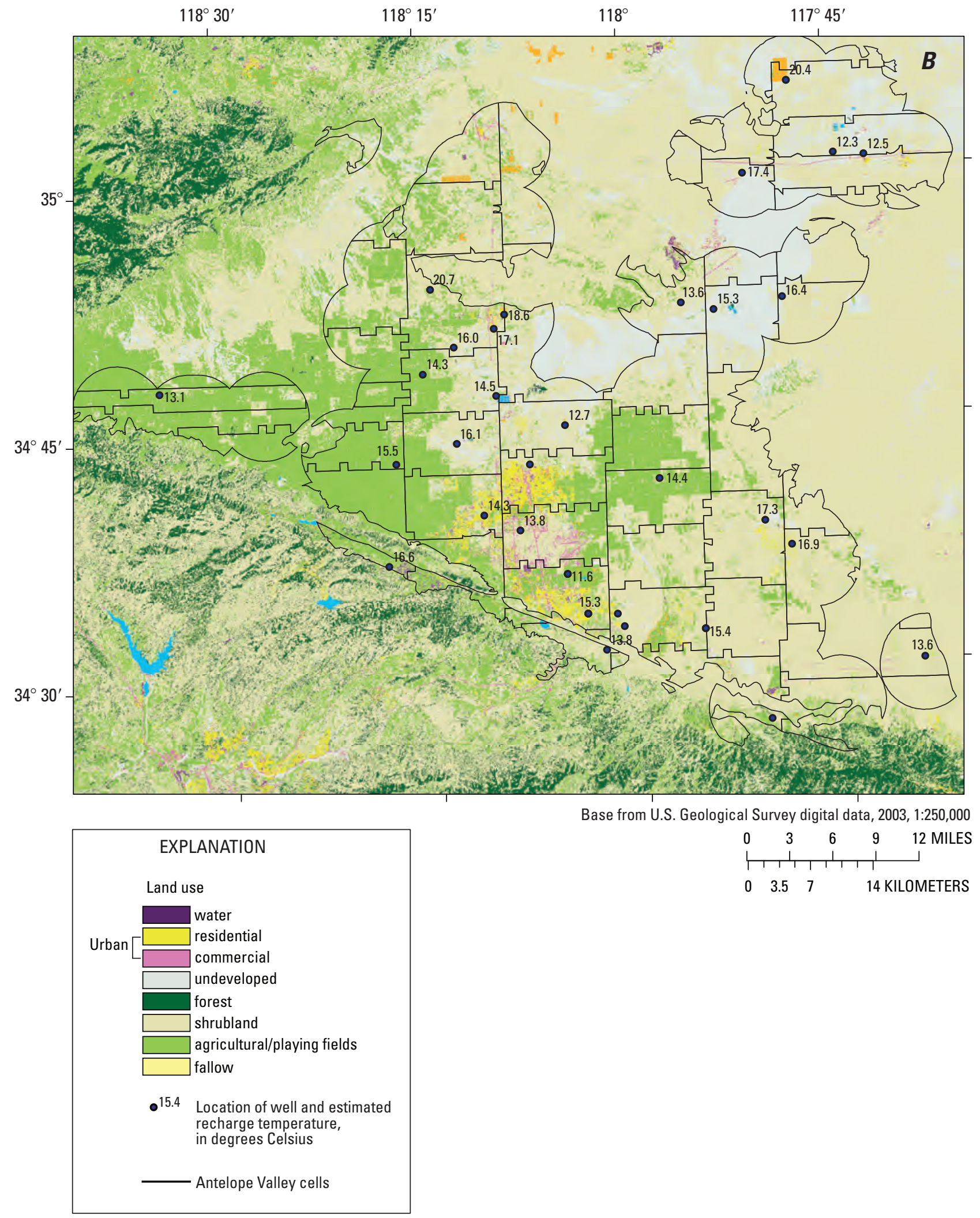

Figure 13. Continued. 


\section{Summary and Conclusions}

The California Ground-Water Ambient Monitoring and Assessment (GAMA) Program was developed to assess the water quality and the susceptibility of ground-water resources to contamination by using tritium and volatile organic compounds (VOC) as indicators. The study areas for this assessment lie within the Mojave River and the Antelope Valley surface-water drainages in the Mojave Desert in San Bernardino, Los Angeles, and Kern Counties. Ground-water samples were collected from 33 wells in the Mojave River Basin (9 in the floodplain aquifer, 15 in the regional aquifer, and 9 in the sewered subset) and 32 wells in the Antelope Valley Basin.

Results of the study show that VOCs were detected slightly more often in the Antelope Valley Basin samples than in the Mojave River Basin samples. In the Mojave River Basin samples, VOCs were detected more frequently in the floodplain aquifer than in the regional aquifer and the sewered subset. Tritium was detected more frequently in the Mojave River Basin samples than in the Antelope Valley Basin samples. In the Mojave River Basin samples, tritium was detected more frequently in the floodplain aquifer than in the regional aquifer and the sewered subset. In general, most of the samples collected for this study contained old water (less than 1 picocurie per liter of ${ }^{3} \mathrm{H}$ ) that was recharged more than 50 years ago (old ground water). The abundance of measured helium-4 $\left({ }^{4} \mathrm{He}\right)$ suggests that much of the water in these areas is thousands to tens of thousands of years old-ages that are in reasonable agreement with previous investigations using ${ }^{4} \mathrm{He}$ or ${ }^{14} \mathrm{C}$ dating.

Trihalomethanes (THM) were detected less frequently in the Mojave River Basin samples than in the Antelope Valley Basin samples. In the Mojave River Basin samples, THMs were detected more frequently in the floodplain aquifer than in the regional aquifer and the sewered subset. Solvents (for example, tetrachloroethylene [PCE] and trichloroethylene [TCE]) were detected more frequently in the Mojave River Basin samples (21 percent) than in the Antelope Valley Basin samples (13 percent). In the Mojave River Basin, solvents were detected less frequently in the samples from the floodplain aquifer ( 22 percent) and the sewered subset ( 22 percent) than in the samples from the regional aquifer (27 percent). Benzene, toluene, ethylbenzene, and xylene (BTEX) were not detected in any of the samples from the Mojave River or the Antelope Valley Basins. Methyl tert-butyl ether (MTBE) was detected in two Mojave River Basin samples and one Antelope Valley Basin sample (3 percent in each area). In the Mojave River Basin samples, based on the detection by area, MTBE was detected more frequently in the samples from the sewered subset (11 percent) than in the samples from the regional aquifer (7 percent); it was not detected in the samples from the floodplain aquifer.
Seventeen different VOCs were detected in the Mojave River and the Antelope Valley Basins. Of these, chloroform was the most frequently detected compound in both basins. PCE also was frequently detected in the Antelope Valley Basin.

Young water (less than 50 years since recharged) in the Mojave River and the Antelope Valley Basins is more likely to be contaminated than old water. However, the presence of tritium is not necessarily an indicator of aquifer susceptibility to contaminants in these areas. VOCs were not detected in 60 percent of the samples that are young water from the Mojave River Basin and in 33 percent of those from the Antelope Valley Basin. VOCs also were not detected in old water in 74 percent of the Mojave River samples and in 73 percent of Antelope Valley samples.

Results of the evaluation of explanatory factors show that aquifer types were not correlated by the statistical tests as an explanatory factor for the number of VOCs detected in the Mojave River Basin. Although VOCs were detected more frequently in the floodplain aquifer than in the regional aquifer and the sewered subset, there was no statistical significance (p-value $=0.7527$, Kruskal-Wallis Rank) in the number of VOCs detected between aquifer types. However, aquifer type was an explanatory factor for the presence of tritium in the Mojave River Basin. Aquifer type was not an explanatory factor for the number of VOCs detected nor for the presence of tritium in the Antelope Valley Basin, although VOCs were detected more frequently in the principal aquifer than in the deep aquifer. Depth to the top perforation was not an explanatory factor for the number of VOCs detected, but was an explanatory factor for the presence of tritium in the Mojave River Basin. Depth to the top perforation was not an explanatory factor for the number of VOCs detected or for the presence of tritium in the Antelope Valley Basin. Land use within $1,640 \mathrm{ft}$ (foot) of the well head was not an explanatory factor for the number of VOCs detected or for the presence of tritium in both the Mojave River and the Antelope Valley Basins.

Although VOCs were detected slightly more frequently in the floodplain aquifer than in the regional aquifer of the sewered subset, there was no apparent spatial pattern to the distribution of VOCs in the Mojave River Basin. On the basis of area-weighted average for VOC detections, the distribution of VOCs detected in the Mojave River Basin was not limited to a specific aquifer. The VOC detections generally seemed sparsely distributed in areas of residential and commercial land use. The distribution of VOCs in the Antelope Valley Basin seemed concentrated in the urban areas and near the mountain front where most of the young water was detected. The differences in the VOC detections and distributions between the two basins probably are related to differences in urban land use within $1,640 \mathrm{ft}$ of the well head. 
Tritium $/{ }^{3} \mathrm{He}$ and apparent ${ }^{4} \mathrm{He}$ ground-water ages in the Mojave River Basin ranged from 0 year in the floodplain aquifer to about 40,000 years in the regional aquifer (with two exceptions). Tritium $/{ }^{3} \mathrm{He}$ and apparent ${ }^{4} \mathrm{He}$ ground-water ages in the Antelope Valley Basin ranged from about 10 years near the mountain front to about 35,000 years north of the mountains. An apparent age of 0 year near the playa in the Antelope Valley Basin is unrealistic and could be adjusted by using a different ${ }^{4} \mathrm{He}$ accumulation rate to provide a more reasonable age.

The stable-isotope composition of the water indicates that recharge along the Mojave River and in the sewered area and recharge in most of the regional aquifer and in the Antelope Valley Basin resulted from precipitation from different climatic conditions. Because the isotopic composition of the samples from the floodplain aquifer and the sewered subset cover a small range of values, the values for the six samples from this group with VOC detections seem more tightly clustered than the values for the samples from the regional aquifer; however, no definite trend is evident. Values for the four samples from the regional aquifer with VOC detections also show no definite trend and are scattered over the half of the samples that are isotopically lighter. The isotopic composition of the 11 samples having VOC detections seem scattered over the heavier range of isotopic compositions and may be related to the proximity of a well to mountain front recharge; however, the samples having VOC detections came from wells located miles from areas of mountain front recharge. Thus, the distribution of the samples that contained one or more VOC detection was not correlated to the source of water.

Noble gases were used to calculate recharge temperatures. Recharge temperatures in ground water in the Mojave River Basin ranged from $7.8^{\circ}$ to $20^{\circ} \mathrm{C}$. Temperatures in ground water were generally lowest in the floodplain aquifer. Temperatures in ground water generally were $2^{\circ}$ to $4^{\circ} \mathrm{C}$ warmer in the sewered subset and $4^{\circ}$ to $5^{\circ} \mathrm{C}$ warmer in the regional aquifer than temperatures in ground water in the floodplain aquifer. Recharge temperatures in ground water in the Antelope Valley Basin ranged from $11.6^{\circ} \mathrm{C}$ to $20.7^{\circ} \mathrm{C}$ and were generally $4^{\circ}$ to $5^{\circ} \mathrm{C}$ warmer than temperatures in ground water in the floodplain aquifer. Cooler recharge temperatures in ground water in the floodplain aquifer indicate recharge is from snowmelt and precipitation runoff from the mountains. Warmer recharge temperatures were present in ground water in the sewered subset and regional aquifer of the Mojave River Basin and in the Antelope Valley Basin.

\section{References Cited}

California Department of Water Resources, 2002, Bulletin 118 - Statewide Groundwater Basin Map Version 3 (October, 2003) digital spatial data of designated groundwater basins of California, data available via web, accessed March, 2003 at URL: http://www.groundwater.water.ca.gov/ bulletin118/basin_maps/index.cfm link for pdf available on September 1, 2004, at URL: http://www.dpla2.water.ca.gov/ publications/groundwater/bulletin118/maps/correct_statewide_basin_map_V3.pdf

Connor, B.F., Rose, D.L., Noriega, M.C., Murtagh, L.K., and Abney, S.R., 1998, Methods of analysis by the U.S., Geological Survey National Water Quality Laboratory: Determination of 86 volatile organic compounds in water by gas chromatography/mass spectrometry, including detections less than reporting limits: U.S. Geological Survey OpenFile Report 97-829, 78 p.

Coplen, T.B., Wildman, J.D., and Chen, J., 1991, Improvements in the gaseous hydrogen-water equilibrium technique for hydrogen isotope analysis: Analytical Chemistry, v. 63, p. 910-912.

Craig, Harmon, 1961, Isotopic variations in meteoric waters: Science, v. 133, p. 1702-1703.

Dawson, B.J., Belitz, Kenneth, Land, Michael, and Danskin, W.R., 2003, Stable isotopes and volatile organic compounds along seven ground-water flow paths in divergent and convergent flow systems, southern California, 2000: U.S. Geological Survey Water-Resources Investigations Report 03-4059, 79 p.

Eaton, G.F., Hudson, G.B., and Moran, J.E., 2004, Tritiumhelium-3 age-dating of groundwater in the Livermore Valley of California: ACS Symposium Series, v. 868, p. 235-245.

Epstein, S., and Mayeda, T., 1953, Variation of O-18 content of water from natural sources: Geochemica et Cosmochemica Acta, v. 4, no. 5, p. 213-214.

Fram, M.S., Bergamaschi, B.Q., Goodwin, K.D., Fujii, Roger, and Clark, J.F., 2003, Processes affecting the trihalomethane concentrations associated with the third injection, storage, and recovery test at Lancaster, Antelope Valley, California, March 1998 through April 1999: U.S. Geological Survey Water-Resources Investigations Report 03-4062, 72 p. 
Grady, S.J., and Casey, G.D., 2000, Occurrence and distribution of methyl tert-butyl ether and other volatile organic compounds in drinking water in the northeast and MidAtlantic regions of the United States, 1993-98: U.S. Geological Survey Water-Resources Investigations Report 00-4228, $123 \mathrm{p}$.

Hamlin, S.N., Belitz, Kenneth, Kraja, S., and Dawson, Barbara, 2002, Ground-water quality in the Santa Ana watershed, California: Overview and data summary: U.S. Geological Survey Water Resource Investigations Report 02-4243, $137 \mathrm{p}$.

Hamlin, S.N., and Belitz, Kenneth, 2005, Relation of the occurrence of volatile organic compounds and pesticides in ground water to hydrogeology and urbanization in the Santa Ana Basin, Southern California: U.S. Geological Survey Scientific Investigations Report 2005-5032, 40 p.

Hewett, D.F., 1954, General geology of the Mojave Desert region California, chap 2, in Jahns, R.H., ed., Geology of Southern California: California Department of Mines and Geology, Bulletin 170, p. 5-20.

Hudson, G.B., Maran, J.E., and Eaton, G.F., 2002, Interpretation of tritium- ${ }^{3}$ helium groundwater ages and associated dissolved noble gas results from public water supply wells in the Los Angeles physiographic basin: Lawrence Livermore National Laboratory, Report UCRL-AR-151447, 25 p.

Izbicki, J.A., and Michel, R.L., 2004, Movement and age of ground water in the western part of the Mojave Desert, southern California, USA: U.S. Geological Survey WaterResources Investigations Report 03-4314, 35 p.

James, John, 1992, Precipitation/evaporation climatology of the Mojave Water Agency: Apple Valley, California: Mojave Water Agency, 21 p., 1 pl.

Koterba, M.T., Wilde, F.D., and Lapham, W.W., 1995, Ground-water data-collection protocols and procedures for the National Water-Quality Assessment Program: Collection and documentation of water-quality samples and related data: U.S. Geological Survey Open-File Report 95-399, $113 \mathrm{p}$.

Koterba, M.T., 1998, Ground-water data-collection protocols and procedures for the National Water-Quality Assessment Program: Collection, documentation, and compilation of required site, well, subsurface, and landscape data for wells: U.S. Geological Survey Water-Resources Investigations Report 98-4107, $91 \mathrm{p}$.

Kulongoski, J.T., Hilton, D.R., and Izbicki, J.A., 2003, Helium isotope studies in the Mojave Desert, California: Implications for groundwater chronology and regional seismicity: Chemical Geology, Elsevier, v. 202, p. 95-113.
Leighton, D.A., and Phillips, S.P., 2003, Simulation of groundwater flow and land subsidence in the Antelope Valley ground-water basin, California: U.S. Geological Survey Water-Resources Investigations Report 03-4016, p. 107.

Londquist, C. J., 1995, Hydrogeology and land subsidence, Antelope Valley, California, in Prince, K.R., Galloway, D.L., and Leake, S.A., eds., U.S. Geological Survey Subsidence Interest Group Conference, Edwards Air Force Base, Antelope Valley, California, November 18-19, 1992, Abstracts and Summary: U.S. Geological Survey Open-File Report 94-0532, p. 38-39.

Londquist, C.J., Rewis, D.L., Galloway, D.L., and McCaffrey, W.F., 1993, Hydrogeology and land subsidence, Edwards Air Force Base, Antelope Valley, California, January 1989December 1991: U.S. Geological Survey Water-Resources Investigations Report 93-4114, p. 74.

Mabey, D.R., 1960, Gravity survey of the western Mojave Desert, California: U.S. Geological Survey Profession Paper 316-D, p. 51-73.

Manning A.H., and Solomon, D. K., 2003, Using noble gases to investigate mountain-front recharge: Journal of Hydrology, Elsevier, v. 275, p. 194-207.

Mazor, Emanuel, 1991, Applied Chemical and Isotopic Groundwater Hydrology: New York, Halsted Press, p. 199-200.

National Safety Council, 2004, Chloroform chemical backgrounders, accessed March 31, 2004, at URL http://www. nsc.org/library/chemical/chlorofo.htm

Ott, R.L., 1993, An Introduction to statistical methods and data analysis: Belmont, Calif., Duxbury Press, 1051 p.

Scott, J.C., 1990, Computerized stratified random site-selection approaches for design of a ground-water-quality sampling network: U.S. Geological Survey Water-Resources Investigations Report 90-4101, 109 p.

Stackleberg, P.E., Kauffman, L.J., Baehr, A.L., and Ayers, M.A., 2000, Comparison of nitrate, pesticides, and volatile organic compounds in samples from monitoring and publicsupply wells, Kirkwood-Cohansey aquifer system, southern New Jersey: U.S. Geological Survey Water-Resources Investigations Report 00-4123, 78 p.

Stamos, C.L., Martin, Peter, Nishikawa, Tracy, and Cox, B.F., 2001, Simulation of ground-water flow in the Mojave River Basin, California: U.S. Geological Survey Water-Resources Investigations Report 01-4002, p. 129. 
State Water Resources Control Board, 2003a, accessed March 28, 2003, at URL http://www.swrcb.ca.gov/gama/cas.html

State Water Resources Control Board, 2003b, accessed March 28, 2003, at URL http://www.swrcb.ca.gov/gama/voluntry. html

U.S. Census Bureau, 2000, Census 2000 data for the state of California: accessed August 14, 2003, at URL http://www. census.gov/census2000/states/ca.html

U. S. Geological Survey, 2003, 1;250,000-scale land use and land cover for California: accessed March 29, 2003, at URL http://edcsgs9.cr.usgs.gov/glis/hyper/guide/1_250_lulcfig/ states/CA.html

Venables, W.N., and Ripley, B.D., 1999, Modern applied statistic with S-Plus, (3d ed.): New York City, Springer-Verlag, $501 \mathrm{p}$.
Walsh, J. F., 1992, Tritium in groundwater as a tool to estimate well vulnerability: Minneapolis, Minn., Minnesota Department of Health, Division of Environmental Health, Section of Water Supply and Well Management, 128 p.

Wilde, F.D., Radtke, D.B., Bigs, Jacob, and Iwatsubo, R.T., 1999, National field manual for the collection of waterquality data: U.S. Geological Survey Techniques of Water-Resources Investigations, book 9, chap A4.3, 91 p. Available at URL http://water.usgs.gov/owq/FieldManual/ chapter4.pdf

Wright, Michael, Belitz, Kenneth, and Johnson, Tyler, 2004, Assessing the susceptibility to contamination of two aquifer systems used for public water supply in the Modesto and Fresno metroppolitan areas, California, 2001 and 2002: U.S. Geological Survey Scientific Investigations Report 2004-5149, 35 p. 
